\title{
Sanal Gerçeklik Anlatısının İzini Sürmek: Trinity VR ve Selyatağı VR Örnekleri ${ }^{1}$
}

\author{
Hakan Erkılıç* \\ Servet Can Dönmez*
}

\section{Özet}

Sanal gerçeklik, kullanıcıların bulundukları konumları ve eylemlerini 360 derece takip ederek duyusal geri bildirimler veren etkileşimli bir bilgisayar teknolojisidir. Arttırılmış gerçeklik ise gerçek görüntüler ile dijital olarak yaratılmış görüntülerin (CGI) bindirilerek kullanıldığı bir sistemdir. İlk ortaya çıktı̆̆ı dönemlerde hantal ve pahalı olan sanal gerçeklik teknolojisinin dijital sinemanın gelişimi ile birlikte günümüzde gündelik kullanıcıların erişimine açılacak kadar küçülmesi ve ucuzlaması, bu teknolojinin olanaklarndan daha fazla faydalanmaya başlayan alanlarn artmasina neden olmuştur. Temelde etkileşimli bir anlatı aracı olan sanal gerçeklik teknolojisini bu bağlamda en etkin olarak dijital oyun sektörü kullanmakla birlikte sinema anlatısının da daima hayal edilen etkileşim ve alternatif anlatı arayışlar neticesinde sanal gerçeklik teknolojisinin teknik imkânlarından daha da fazla faydalanmaya başladığını söylemek yanlış olmayacaktır. Zaman ve mekân kurgusunun gerçekle olan bağı, sinemasal zaman ve mekânın kalitesi ve etkileşimsellik, bu üç temel çıkış noktasından ilk ikisi sinema anlatısının seyirciyle özdeşlik kurması ve amacına ulaşabilmesi noktasında çok büyük pay sahibidir. Etkileşimsellik noktasında ise sanal gerçekliğin tüm anlatılarm ve sanatlarm hatta sinemanın da ötesinde bir noktada durduğu iddia edilebilir. Bu bağlamda şu soruların yanıtı aranmaktadır: Sanal gerçeklik teknolojisi ile sinemanın kesiştiği ve ayrildığı noktalar? Benzerlikleri ve farklılıları? Anlatı yapıları ve teknikleri? Yarattıkları gerçeklik algıları? Benzer soruların günümüzde daha da fazla akıllara gelmesinin temel nedeni olarak gelişen dijital teknoloji ile birlikte buna hızla adapte olan sinema teknolojisinin yaşadiğı dijital dönüşüm gösterilebilir. Bu noktadan hareketle bu çalışmada öncelikle sanal gerçeklik teknolojisi ve sinemanın benzerlikleri ve farklıliklarn üzerinde durularak ana akım ve büyük prodüksiyonlu yapımlara bir örnek olarak gösterilen Trinity VR (Boivin, 2018) isimli yapım ile yerli ve bağımsız yapımlara örnek olarak Selyatağı VR (Tortum, 2018) isimli sanal gerçeklik filmlerinin biçemsel analizi yapılarak sanal gerçeklik teknolojisi ile değişen sinema anlatısının yapısı üzerine sorulara yanıtlar aranacaktır.

Anahtar Kelimler: Sanal gerçeklik, dijital sinema, 360 derece film, anlatı, etkileşimsellik

*ORCID: 0000-0002-0828-3848 \& 0000-0003-2590-3102

E-Mail: ehakan@mersin.edu.tr \& servetcandonmez@gmail.com

DOI: 10.31122/sinefilozofi.674107

Geliş Tarihi - Recieved: 15.01.2020

Kabul Tarihi - Accepted: 15.05.2020

${ }^{1}$ Bu makale Mersin Üniversitesi"2019-1-AP4-3395" nolu Bilimsel Araştırma Projesi desteği ile hazırlanmıştır 


\title{
Tracing Virtual Reality Narrative: Trinity VR and Selyatağı VR Examples
}

\author{
Hakan Erkıliç* \\ Servet Can Dönmez*
}

\begin{abstract}
Virtual reality is an interactive computer technology that gives users sensory feedback by tracking their positions and actions 360 degrees. Augmented reality is a system in which real images and digitally generated images (CGI) are superimposed. The fact that virtual reality technology, which was cumbersome and expensive at the time it first appeared, became smaller with the development of digital cinema and became cheap for the access of everyday users, and the areas that started to benefit more from the opportunities of this technology increased. Although virtual reality technology, which is basically an interactive narrative tool, uses the digital game sector as the most effective in this context, it will not be wrong to say that cinema narrative has always started to benefit more from the technical possibilities of virtual reality technology as a result of imaginable interaction and alternative narrative searches. The relation of time and space to reality, the quality of cinema time and space and interactive, and the first two of these three main points of departure have a big share in the way that the narrative of the cinema narrates and reaches its purpose. In the point of interactivity, it can be claimed that virtual reality stands at a point beyond all narratives and arts, even cinema. In this context, the answers to the following questions are sought: The intersection and separation of virtual reality technology and cinema? Similarities and differences? Narrative structures and techniques? Perceptions of reality they create? As the main reason why similar questions are becoming more and more common nowadays, the digital transformation experienced by the rapidly adapting cinema technology can be shown. From this point of view, in this study, Trinity VR (Boivin, 2018), which is shown as an example of mainstream and large production productions with emphasis on the similarities and differences of virtual reality technology and cinema, and Selyatağ $\mathrm{V}$ VR (Tortum, 2018) as an example. by style analyzing virtual reality films, answers will be sought on the structure of cinema narrative changing with virtual reality technology.
\end{abstract}

Keywords: Virtual reality, 360 degree film, digital cinema, narrative, interactivity

*ORCID: 0000-0002-0828-3848 \& 0000-0003-2590-3102

E-Mail: ehakan@mersin.edu.tr \& servetcandonmez@gmail.com

DOI: 10.31122/sinefilozofi.674107

Received - Geliș Tarihi: 15.01.2020

Accepted - Kabul Tarihi: 15.05.2020 


\section{Giriş}

Harari'nin (2015) "dedikodu" olarak isimlendirdiği iletişim kurabilme yetisi insanı diğer canlılardan ayıran en temel özelliktir. Harari' nin kast ettiği dedikodu olayları nedensonuç ilişkisi içerisinde değerlendirip, gün sonunda olanların kritiğini yaparak karşılıklı bir fikir alışverişinde bulunup, bilgi ve birikimlerini gelecek nesillere aktarabilme becerisidir. İnsanlık, mağara duvarlarına çizerek, mitler ve destanlar yaratarak, hikâyeler anlatarak, roman ve yazarak, filmler yaparak zaman içerisinde bu yetisini geliştirmiştir. Bugün geldiğimiz noktada farklı mecra ve formlarda bir yandan dünya ve kendi tarihinin yazımına katkıda bulunmuş bir yandan da yeni ve farklı iletişim araçları arayışları sonucunda yaygın olarak kullanılan yeni iletişim araçlarının gelişmesine ön ayak olmuştur.

Resim, heykel, mimari, dans, şiir, müzik ve daha sonrasında yedinci sanat olarak kabul edilen sinema da dâhil olmak üzere tüm sanat formları temelinde hep bir hikâye anlatma fikri yatmaktadır. Christopher Isherwood'un (2016:48) Prater'in Menekşesi adlı romanının kahramanı Mr. Isherwood 1933 yılında Londra'daki en eski stüdyolardan Imperial Bulldog stüdyosunda yazım aşamasına katkıda bulunduğu senaryonun çekimleri sırasında sesin gelişi ile birlikte stüdyodaki değişimleri anlatır ve gelecek üzerine öngörülerde bulunur. "Kimse sırada ne olduğunu bilmiyordu: Belki tat, koku ya da streskopi, hatta perdeden fırlayıp seyircilerin arasında dolaşacak bir cihaz. Hiçbir şey imkânsız değildi". Isherwood'un da dikkat çektiği gibi teknolojik gelişmeler (dijitalleşme, CGI ve VFX uygulamaları) günümüzde sinemada birçok şeyi olanaklı kılmaya başladı. İnsan doğayı fotoğraf makinesi ile durağan görüntü olarak saptamış, hareketli görüntüyü pelikül üzerinde yakalamış ve günümüzde insanlığın algısını zorlayacak şekilde 360 derece gerçekliği kaydetmeye başlamıştır. İnsanlık tarihi içerisinde çeşitli teknolojik ve kültürel değişimlerin yaşanması ile farklı formlara bürünerek varlığını daima sürdüren tüm sanat formları bugün yeni medya ortamlarında kendilerini dijitale adapte etmektedirler. Tarihi kökeni daha eskilere dayanmakla birlikte farklı teknolojik gelişmelerin yöndeşmesi sonucu olarak ortaya çıkan bir yeni medya aracı olarak "Virtual Reality" (VR) yani sanal gerçeklik teknolojisi bugün insanın hikâye anlatma aracı olarak kullandığı en yeni araçlardan birisi olarak yeniden gündeme gelmeye başlamıştır. Dolayısı ile içerisinde kendisinden önceki tüm anlatı formların barındıran ancak bunlardan daha da farklı olarak kendine has bir yapısı olan bu yeni aracın anlatısına ait dil ve kodların tanımlanması ve kuramsal altyapısının belirli temellerinin ortaya konulabilmesi için hem teorik hem de pratik araştırmaların yapılması gerekmektedir.

$\mathrm{Bu}$ çalışmanın amacı sanal gerçeklik teknolojisi ve sinemanın benzerlikleri ve farklılıkları üzerinden ana akım ve büyük prodüksiyonlu yapımlara bir örnek olarak gösterilen Trinity VR (Boivin, 2018) isimli yapım ile yerli ve bağımsız yapımlara örnek olarak Selyatağı VR (Tortum, 2018) isimli sanal gerçeklik filmlerinin analizini yaprak, sanal gerçeklik teknolojisinin anlatı yapısının ve kodlarının saptanabilmesidir. Bu çerçevede makalede yöntem olarak birbiri ile ilişkili dört basamaklı bir model ile VR yapımlar çözümlenecektir:

1) Ele alınan VR yapımlar (Trinity VR ve Selyatağı VR), sinematik bir anlatıma sahip oldukları için çözümleme yöntemi olarak sinemadaki biçem analizinden hareket edilecektir. ${ }^{1}$ Sinemada biçem, filmin tekniğinin sistematik ve belirlenmiş kullanımını ifade eder: anlatı yapısı (öykü), sinematografi (kamera hareketleri ve çekim ölçekleri), mizansen

\footnotetext{
${ }^{1}$ Yöntem olarak, sinemasal sanal gerçeklik üzerine Perez'in (2016) çözümleme yöntemi ilk örmeklerdendir. Perez' in uyguladığı VR film analizi, Lewis'in (2014) film analizi yöntemine ve Steuer'in (1992) "orada olma hissi" (telepresence) teorisine dayanır. Ayrıca yapım ekibi görüşmelerinin sonuçları da dikkate alınmıştır.
} 
(çerçeveleme, aydınlatma, dekor ve kostüm), kurgu (kesme ve geçişler) ve ses (diyalog, müzik, efekt, dış ses, vb.) gibi yapım unsurlarını içerir². Biçem analizi (Bordwell ve Thompson, 2011; Giannetti, 2002) de bir filme, yönetmen sinemasına veya bir döneme anlatı, mizansen, sinematografi, kurgu ve ses gibi yapım özellikleri üzerinden odaklanır. Bu çerçevede VR yapımlar sinemasal biçem ve anlatı formlarından nasıl yararlanıyorlar sorusuna yanit aranacaktır.

2) Film çözümlemesini sanal gerçekliğe uyarlamak, özellikle seyircinin deneyimine ve etkileşim kurma kapasitesine açıklamayı da gerektirmektedir. Bu bakış Steuer'un (1992) "orada olma hissi" (telepresence) kavramını dikkate almayı zorunlu kılar. Çözümleme içinde VR yapımların "orada olma hisi" ni nasıl gerçekleştirdikleri de açıklanmaya çalışılacaktır.

3) Özellikle Trinity $V R^{\prime}$ da gördüğümüz animasyon /CGI uygulamaları ve oyun motoru altyapısı kullanımlarından dolayı oyun anlatımı ile VR yapımlar arasındaki ilişkisiye de bakılacaktır.

Çalışmada, çözümlemelerden elde edilecek veriler birbirleriyle ilişkilendirilerek sanal gerçeklik içeriği/deneyimi hazırlanırken hangi kodların kullanıldığı ve bu kodların sinema kodları ile karşılaştırıldığında ne kadarının kullanılabildiği veya kullanılamadığı, sanal gerçekliğe özel hangi parametrelerin işlevsel olduğu ve sanal gerçeklik anlatısına özgü hangi kodların geliştirildiği sorularına yanıt aranacaktır.

\section{Sanal Gerçeklik Nedir?}

Sherman ve Craig'e (2019: 6) insanlık tarihini var olan fikirleri paylaşma ve bunu yapabilmek için ise kullanılan çeşitli medya araçlarının gelişim tarihi olarak özetlemektedir. $\mathrm{Bu}$ fikirden hareketle düşünüldüğ̈ünde insanlık tarihine ilişkin ilk belgeleri oluşturan mağara resimleri bu fikir paylaşma ve hikâye anlatma aracı olarak yeniden bir gerçekliğin canlandırılması açısından sanal gerçeklik teknolojisinin ilk örnekleri olarak kabul edilmektedir. Bugün teknolojik olarak geldiği noktadan bakıldığında sanal gerçeklik temel olarak kullanıcının bulunduğu konumu ve kullanıcının eylemlerini takip eden ve en az bir duyu yolu ile geri bildirim vererek kullanıcın o ortamdaki varlığını simule eden (yapay ve üç boyutlu dünya, orada bulunma, gerçek dünyadaki gibi duyusal tepkiler verme) etkileşimli bir bilgisayar teknolojisidir (Jerald, 2016: 9, Sherman ve Craig, 2003:13). Sanal gerçeklik deneyiminin sağlanması için sanal gerçekliğin dört temel bileşeni içermesi gerektiği belirtilmektedir: sanal çevre, sanal temsil, duyusal geribildirim (kullanıcının hareketlerine karşı tepki) ve etkileşim (Sherman vd.2009).

Lev Manovich (2001: 8), sanal gerçekliği kökeni eski olan ancak artan dijitalleşme ile yeniden hayat bulan yeni medya aracı olarak tanımlamaktadır. Geleneksel medyadan farklı olarak sanal ortamlarda kullanıcılar o ortamda olma ve fiziksel olarak farklı bir ortamda bulunma deneyimini yaşamaktadır. Steuer (1992:79- 87), sanal gerçeklik deneyiminde "bir çevrede olma" halini, "orada olma" hissini telepresence kavramı ile açıklıyor. "Orada olma hissi" (telepresence), 'bir iletişim aracı vasıtasıyla gerçek veya simüle edilmiş bir ortamda "var olma deneyimi", "fiziksel çevreden öte aracılı çevrede ne hissedildiğini" tanımlamaktadır. Yani hayali bir yerde olma etkisi yaratmak sanal gerçekliğin en önemli özelliğini oluşturmaktadır. Steuer'a göre "orada olma hissi" için iki önemli belirleyici faktör vardır: tanıklık (vividness) ve etkileşim (interactivity). Tanıklık, bir teknolojinin duyusal aracılı bir ortam yaratma kapasitesini ifade eder (sarmalayan özelliği). Sanal gerçekliğin sarmalama (immersion) özelliği ile tanıklığı mümkün kılar. Sanal dünyada olma yanılsaması kullanıcıyı ses ve görüntüyle kuşatarak gerçekten orada olduğuna inandırabilmektedir. Sanal ortamlarda "orada olma hissi", sarmalama (immersiyon) ile çok yakın bir ilişki

\footnotetext{
${ }^{2}$ Biçem analizi genel değerlendirmesi için bakınız Serter (2005).
} 
içerisindedir. Bilgisayarlar aracılığı ile insan algısında gerçeklik illüzyonu yaratan sarmalama, orada olma hissi için mutlaka olması gereken bir öğe olarak kabul edilmektedir. (Slater ve Wilbur, 1997, Witmer ve Singer, 1998). Lombard ve Ditton (1997) ise orda bulunma hissini, aracılı deneyimin aracısızmış gibi illüzyonun yaratılması olarak tanımlamaktadır. Dolayısı ile orada olma hissi ve sarmalayan birbiri ile iç içe geçmiş bir şekilde işleyen bir mekanizma olarak sanal gerçeklik deneyimlerinin ana hedeflerinin en temel öğeleridir. Bu çerçevede sanal gerçeklik, kullanıcının teknolojik yönlerinden öte deneyime sahip algısı ile tanımlanmaktadır. Böylece, etkili bir sanal gerçeklik deneyimi gerçek ortamından habersiz olmaya ve sanal ortamdaki varlığa odaklanmaya neden olur. "Orada olmak", kişinin bir medya aracılığıyla sunulan hayali bir ortamı tahayyülü temsil eder. Tanıklık, biçimsel özellikleriyle tanımlanan aracı bir ortamın temsili zenginliği anlamına gelir; yani, bir ortamın duyulara bilgi sunma biçimi. Tanıklık, tamamen bir ortamın teknik özelliklerine bağlı olarak uyarıcıdır. Steuer, sarmalama (immersive) işlemi sonucu gelişen tanıklık'ın iki ana bileşeni olduğunu belirtir: derinlik (depth) ve genişlik (breadth). Tanıklık, aynı anda sunulan duyusal boyutların sayısını ifade eden duyusal genişlik ile bu algısal kanalların her birinin içindeki çözünürlüğü ifade eden duyusal derinlikten oluşur. Enformasyon derinliği, kullanıcının sanal bir ortamda etkileşime girdiğinde aldığı sinyallerdeki veri miktarı ve kalitesine karşılık gelir. Kullanıcı için bu, bir ekranın çözünürlüğünü, ortam grafiklerinin ve sistemin ses çıkışının karmaşıklığını ifade edebilir. Genişlik, bir iletişim ortamının duyular boyunca bilgi sunma yeteneğinin bir fonksiyonudur. Steuer, enformasyonun genişliğini "aynı anda sunulan duyusal boyutların sayısı" olarak tanımlar. Sanal ortam deneyimi, tüm duyularınızı harekete geçirirse geniş bir bilgi yelpazesine sahip olur. Çoğu sanal ortam deneyimi, görsel ve işitsel bileşenleri diğer duyusal uyarıcı faktörlere göre önceliklendirir, ancak giderek artan sayıda bilim insanı kullanıcıların dokunma duygusunu birleştirmenin yollarını araştırmaktadır. Kullanıcıya geri bildirim ve dokunma etkileşimi veren sistemlere haptik sistemler denilmektedir. Bu teknolojik değişkenler sanal gerçeklikte insan deneyimini mümkün kılmaktadır. Etkileşim, kullanıcının sanal ortamın biçimini veya içeriğini ne ölçüde etkileyebileceğini ifade eder ve bunlar teknolojinin hızı (speed), menzili (range) ve haritalaması (mapping) ile belirlenir. Bu üç faktör, örneğin internet hızı veya cihaz özellikleri ile değişiklik gösterebilir. Etkileşime ise üç faktör katkıda bulunur: girdinin aracılık ortamına asimile edilme hızını ifade eden hız; herhangi bir zamanda eylem için olanakların sayısını ifade eden menzil; ve bir sistemin kontrollerini aracılı ortamdaki değişikliklerle doğal ve öngörülebilir bir şekilde eşleme yeteneğini ifade eden haritalama. Böylece "orada olma hissi", kişinin medya aracılığıyla sunulan hayali bir ortamın zihinsel projeksiyonunu temsil eder. Steuer (1992), sanal gerçekliği tanımlamanın anahtarının teknolojik donanımda değil, insan deneyiminde ve bu "özün varlığı" temelinde yattığını savunur. Sanal Gerçeklik, duyusal uyarım yoluyla bizi "hayali bir gerçekliğe" sokmak için tasarlanmış bir teknolojidir ve ortak bir algısal aracılık yanılsamasına dayanmaktadır. Sanal gerçeklik aracılığıyla insan duyuları ne kadar uyarılırsa, "orda olma hissi" o kadar tetiklenir. Öncelikle görme ve işitme gibi iki temel duyunun uyarılmasından hareket den sanal gerçeklik deneyimlerine dokunma, koku hatta tat gibi duyularda eklenmektedir. Böylece, zamanla orada olma hissi haptik sitemler deneyimi ile daha da gelişecek ve daha "gerçek" hale gelecektir.

Sanal gerçeklik teknolojisinin terminolojisinde birçok farklı kavram yer almaktadır, arttırılmış gerçeklik (Augmented Reality), karma gerçeklik (Mixed Reality), point cloud ${ }^{3}$ ve hacimsel (volumetric) kayıt teknolojisi gibi, bunların arasında en çok kafa karışıklığına sebep olan kavram ise 360 derece video kavramıdır. 360 derece video birden çok kameranın küresel

\footnotetext{
${ }^{3}$ Nokta bulutları, 3D tarayıcılar ile üretilen ve nesnelerin 3 boyutlu uzayda dış yüzeylerini ölçen ve 3D olarak veriye çeviren teknoloji.
} 
(spherical) olarak 360 derece bir görüntü kaydetmesi ile elde edilen video formatına verilen isimdir. Sanal gerçeklik teknolojisinde bilgisayar dolayımlı etkileşimli bir katılım ve 3 boyutlu bir dünyada var olma duygusu olduğundan birden fazla kamera ile küresel olarak kaydedilen videoları sanal gerçeklik olarak tanımlamak yanlış olacaktır; aralarındaki benzerlik sadece sanal gerçeklik başlıkları ile izleme imkânı veren bir video formatı olmasindan ileri gelmektedir (Fonseca, 2016). Sarah Thomas (2019: 454), bu durumun bir sonucu olarak iki ana formun ortaya çıktığını öne sürmektedir; Gerçek sanal gerçeklik (True Virtual Reality-TVR) ve sinematik sanal gerçeklik (Cinematic Virtual Reality-CVR). TVR tam etkileşimli ve kullanıcıların oyun motorları aracılığı ile hareketi de kontrol edebildiği bir deneyim sunarken CVR kullanıcıya istediği noktaya bakma özgürlüğü veren 360 derece stereoskopik (3D) bir video deneyimi sunmaktadır.

Murray (2012: 101-102) sanal gerçekliğin kullanıcılara geleneksel medyadan daha zengin bir deneyim sunduğunu ve bunu alternatif perspektifler, oryantasyona ve sarmayalan ortama erişim ile sağladığını belirtmektedir. Sanal gerçeklik sinemasal anlatımların dışında haber ve belgesel yapımlarında da kullanılmaktadır. Hali hazırda farklı platformlar üzerinden erişilebilen New York Times VR'1n (Ünal ve Dönmez, 2018) sanal gerçeklik belgeselleri; Emblematic tarafından hazırlanan “Greenland Melting (2017) isimli etkileşimli belgesel; Steam platformu üzerinden erişilebilen tamamen oyun motoru ile hazırlanmış olan Eleven Eleven ve The Great $C$ gibi farklı denemeler örneklendirilebilir. Farklı hikâye anlatımı yaklaşımları ile hazırlanmış içeriklerin sayısı giderek artmaktadır. Artan içerikler ile birlikte sanal gerçeklik anlatısının dilinin ve kodlarının belirlenmesi için daha fazla veri oluşmaya ve birikmeye devam etmektedir. Bu bağlamda Uricchio'nun (2016) sorduğu soru anlamlıdır: VR sinema değilse öyleyse nedir? Nash'ın (2018a:97-100) özellikle VR belgeseller üzerinden tartıştığı ve geliştirdiği ufuk açıcı saptamalar, VR sinematik anlatılar için de önemli olan etik ve estetik sorunlara dikkat çekmektedir ${ }^{4}$. Genel uylaşımlardan hareketle VR, yeni bir medium/ortam, sarmalayan (immersif) eğlence, bir "deneyim" olarak tarif edilmektedir.

Sanal gerçeklik anlatısının dinamik yapısı ve empatiyi en üst düzeye çıkartarak özdeşleşmeyi sağlaması, kullanıcının başka bir bedende var olarak eylemi deneyimleyerek yaşamış gibi bir duygu hissetmesini sağlaması bu anlatı aracının en çok tartışılan ve teknik detaylarını çözme noktasında en önemli sorulardan birisidir. Benzeri sorulara yanıt bulabilmek için yürütülen çalışmalar doğal olarak en yakın öncülü olan sinema anlatısının kodları ve biçimi üzerinden çıkarımlarda bulunmaya çalışmaktadır. Eun Seo Bang ve Çağlar Yildırım (2018) "Virtually Empathetic?: Examining the Effects of Virtual Reality Storytelling on Empathy" isimli çalışmasında sanal gerçekliğin empati yaratma ve empati düzeyi üzerine etkisini araştırmak üzere "After Solitary" isimli bir 360 derece videoyu 15'i kadın 29'u erkek olmak üzere toplamda 44 adet öğrenciye izleterek, videoyu bilgisayar üzerinden Youtube aracılığı ile izleyenler ile sanal gerçeklik başlıkları üzerinden izleyenler arasında empati düzeyin üzerinde farklılık olup olmadığını sorgulamışlardır.

Bang ve Yıldırım çalışmalarının sonucunda bir belgeseli sanal gerçeklik başlıkları üzerinden izleme ile bilgisayar ekranı üzerinden izleme arasında empati farklılığı noktasında

\footnotetext{
${ }^{4}$ Biz, bu makalede VR sinematik anlatılara, kurmaca yapılara odaklanıyoruz. VR belgeselleri ayrı bir çalışmada inceleyeceğiz. Bu konuda bakınız (Leotta ve Ross, 2018; Nash, 2018b). Nash (2018a), sanal gerçeklik deneyiminde Steuer' dan (1992) hareketle "bir çevrede olma" mevcudiyeti, belgesel için "orada olma" hissinin önemine; çerçevenin kaybı, simüle edilmiş bir 'simüle' alan içinde konumlandırmaya; duygusal gerçeklik hissine; Bazin' in toplam sinema mitinin gerçekleşmesine ve kullanıcının çerçeveyi belirlemesine; sanal gerçeklik belgesel yapımının disiplinler arası bir hal alarak kodlayıcılar ve tasarımcılarla birlikte gerçekleştirilmesine dikkat çeker.
} 
bir değişiklik veya sanal gerçeklik başlıkları lehine bir farklılık göremediklerini belirtmişlerdir. İzleme biçiminin veya aracının değişimi sonucunda içeriğin etkisinin araştırılması adına önemli olan bu çalışma temel savı noktasında sorun teşkil etmektedir. Sanal gerçeklik anlatısının anlamlandırılması ve empati düzeyi üzerine araştırma yapılması öngörülürken sanal gerçeklik kavramının temel prensip ve tanımlarından sapmamaya özen gösterilmesi gerekmektedir, bu bağlamda Youtube üzerinden erişilebilen sınırlı bir görüntü kalitesine sahip 360 derece bir video ile aynı videonun $\mathrm{HMD}^{\prime}$ ler ${ }^{5}$ üzerinden izlenmesinin sanal gerçeklik deneyimine etkisi doğru bir yaklaşım olarak görünmemektedir. Çünkü 360 derece videolar gerçek sanal gerçeklik içerikleri değillerdir. Sanal gerçeklik içeriklerinin en önemli özelliklerinden birisi olan 3 boyutlu uzamda stereoskopik olarak mekânı özgürce deneyimleyerek bedensel varlığın sanal mekânda hissedilmesi duygusudur. Dolayısı ile daha öncede belirtildiği üzere 360 derece videolar ile gerçek sanal gerçeklik içerikleri arasında böyle bir kıyasa gidilmesi çıkarımlar noktasında sorunlar doğurabilmektedir.

Gödde, Gabler, Siegmung ve Braun "Cinematic Narration in VR - Rethinking Film Conventions for 360 Degrees" (2018) başlıklı çalışmasında sinema anlatısında kullanılan bazı kodların sanal gerçeklik anlatısında da işleyip işlemediğini deney grupları üzerinden araştırmıştır. Bu çalışmada yine Youtube üzerinden erişilebilen ücretsiz 360 derece videolar kullanılmıştır. Çalışmada sanal gerçeklik içeriklerinden kullanıcıların bakacağı yerin video içerisinde ses veya görüntü içerisindeki öğeler ile yönlendirilip yönlendirilemeyeceğini araştırılmıştır. Çalışma sonucunda bakış, hareket, ses, içerik ve perspektif içi öğeler gibi birtakım öğeler ile kullanıcının bakışının yönlendirilebileceği sonucuna varılmıştır. Bu yönlendirmeler sinemada yönetmenin çerçeveleme ve çerçeve içerisindeki öğeler ile hikâye anlatma tekniklerinin sanal gerçeklik içeriklerindeki karşılığ olarak görülebilir. Ancak bu çalışmada yine gerçek sanal gerçeklik içerikleri yerine 360 derece videolar kullanıldığ göz önüne alınmalıdır, bununla birlikte Thomas' in (2019) sinematik sanal gerçeklik (CVR) olarak tanımladığı içerikler üzerinden gerçek sanal gerçeklik içerikleri üzerinde de etkili olabilecek sonuçlara varıldığı görülmektedir.

\section{Sinema ve Sanal Gerçeklik İlişkisi}

The Jungle Book-Through Mowgli's Eyes (2016), Dunkirk-VR Experince (2017) ve Interactive Paranormal Activity Seance (2015) (Dönmez ve Erkıliç, 2019) gibi büyük bütçeli Hollywood yapımlarının tanıtımı için kullanılan kısa sanal gerçeklik içerikleri ile Robert Rodriguez'in The Limit VR (2018) isimli 180 derece olarak tasarlanmış olan film denemesi gibi örnekler sektörün önde gelen büyük yapımcılarının sanal gerçekliğe olan ilgisinin ve yavaş yavaş oluşmaya başlayan bu yeni pazarın kurallarını belirlemeye ilişkin isteklerinin bir göstergesidir. Bununla birlikte Steven Spielberg tarafından yönetilen Ready Player One (2018) isimli filmin sanal gerçeklik teknolojisine duyulan ilgi ve merakın artmasında önemli olduğunu söylemek mümkündür. Sözlü ve yazılı edebiyat gibi geleneksel anlatıların diegetik yapısına karşın tiyatro ve sinema gibi görsel ve işitsel anlatıların mimetik yani taklide dayalı bir yapısı bulunmaktadır. Sanal gerçeklik anlatısı ise daha çok mimetik bir yapıya sahip olmakla birlikte içerisinde diegetik öğeleri de barındırmaktadır. Bu bağlamda sanal gerçeklik anlatısını anlamlandırabilmek için en yakın akrabası olan sinema anlatısı ile olan benzerlik ve farklılıkları üzerinden hareket etmek iyi bir başlangıç noktası olacaktır.

Sinemanın anlatı yapısı ile sanal gerçeklik anlatısının karşı karşıya getirildiği noktalarda ise sinema anlatısının kavramları çerçevesinde şekillenmektedir. Bunlardan ilki anlatının zaman ve mekân kurgusunun gerçek zaman ve mekân ile olan bağı, ikincisi

\footnotetext{
${ }^{5}$ Head mounted display, günümüzde sanal gerçeklik başlıkları ya da gözlükleri için kullanılan genel kisaltma.
} 
seyircinin sinemasal zaman ve mekânı ne kadar özümseyebildiği ve sonuncusu ise etkileşimselliktir (Aylet ve Louchart, 2003). İlk iki aks yani sinemasal mekân ve zaman kurgusunun kalitesi ve işleyişinin seyircinin filmle kuracağı özdeşlik bakımından önem arz etmektedir, aynı şekilde sanal gerçeklik içerikleri için aynı koşulların geçerli olduğunu söylemek mümkündür. Sinemaya ek olarak "orada olma” duygusu yaratma, sarmalayan ve uzamsal bir deneyim üzerine anlatısını inşa eden sanal gerçekliğin bu noktada bir adım daha önde olması doğası gereği normaldir. Etkileşim konusunda ise sinemanın seyircisi ile etkileşimli bir bağ kurabilmesi ancak Netflix'in "Black Mirror: Bandersnatch" (2018) isimli dizide olduğu gibi (yönetmen ve yapımcının belirlediği sınırlar içinde) yine dijital teknolojinin gelişen imkânları ile mümkün olabilmektedir. Sinemadan farklı olarak sanal gerçeklik anlatısının önemli bir özelliğini de etkileşimsellik oluşturmaktadır.

Sinemanın ortaya çıktığı ilk y1llardan bu yana süregelen ve sinemanın seyircisi ile kurduğu bağ ve özdeşleşme duygusunu nasıl yarattığı yani sinemanın büyülü dünyasının sistematiği üzerine var olan tartışmalar güncelliğini korumakta ve bugün gelinen noktada ise dijital sinemanın yapısı üzerinden tartışılmaya devam etmektedir. En genel yapısı itibarı ile "biçimciler" ve "gerçekçiler" olarak iki ana aks üzerinden devam eden sinemanın yarattı̆̆ 1 zamansal ve mekânsal algının başarısının ve seyircinin bilincinin bu süreçteki varlığı üzerine bir tartışma yürütmektedir. Biçimci bakış açısı sinemasal gerçekliğin hem çekim sırasında çerçeve içi düzenlemeler ile hem de çekim sonrasında kurgusal olarak yapılacak düzenlemeler ile sağlanabileceğini öne sürmektedir. Buna karşıllk gerçekçi aks ise algısal olarak gerçekliğin en üst düzeye çıkarılabilmesinin kesintisiz çekim, minimum kurgu ve insan algısına en yakın olan ölçek ve çekimler ile elde edilebileceğini savunmaktadır. Dolayısı ile sanal gerçeklik anlatısının gerçekçi aksa daha yakın olduğunu söylemek yanlış olmayacaktır. Bu bağlamda gerçekçi kurama yakından bakmak faydalı olacaktır.

Kracauer (2015) "fiziksel gerçekliğin kurtuluşu" alt başlığını içeren çalışmasında görüntünün bir yeniden üretim olduğunu ve çok yönlü olan fiziksel gerçekliğin yönetmenin kendisine en uygun gördüğünü seçerek filme alması ile ortaya çıtı̆̆ın öne sürmektedir. Kracauer gördüğümüz dünyanın yönetmenin hammaddesi olduğunu dolayısı ile bu hammaddenin ötesine geçerek diğer geleneksel sanatlara benzemeye çalışan sinemanın kendi özünü kaybettiğini iddia etmektedir (Andrew, 2010: 191-195). Andre Bazin ise sinemaya ilişkin fikirlerini ontolojik bir bakış temelinde şekillendirmektedir. Heykel ve resim gibi sanatların temelinde eski Mısır'da var olan mumyalama geleneği ile ölüme karşı açılan bir mücadele olduğunu söyleyen Bazin (1966: 30-31), bu durumun portre yahut modelin ontolojik varlığının yerine onların hatırlama yolu ile ruhani olan ölümden kurtulmaya yarayan bir araç olarak görülmesinden kaynaklandığını söylemektedir. Sinemanın temellerini ise Rönesans ile ortaya çıkmaya başlayan ve son şeklini barok resimle bulan plastik sanatların en gelişmiş formu olarak görmektedir. Niepce'nin fotoğrafı ve Lumiere kardeşlerin sinematografı ile sinema sanatın barok döneme bir son vererek gerçekliğe öykünme açmazından kurtarmıştır. Tüm sinema miti isimli başlıklı yazısında Bazin (2011: 23-31), Muybridge, Melies, Edison ve Lumiere kardeşler gibi birçok ismin tutku ve hayallerinin peşinden koşması, sinemanın doğuşu ve gelişimi bakımından tüm sinema miti içerisinde sinema tarihindeki yerini almıştır. İlerleyen yıllarda ortaya çıkan ve daha gerçekçi olan renkli ve sesli filmler, 3D, Dolby Sound, IMAX ve sanal gerçeklik gibi yeniliklerin de günümüzde bu mitin devamı olduğunu söylemek mümkündür (Stam, 2014: 86, Leotta ve Ross, 2018: 151, Nash, 2018a: 98). Bazin sinema görüntüsünün gerçeğin yeniden üretilmesi veya dönüştürülmesi ile değil gerçeğin içerisinde seçimler yapılması ile oluştuğunu söylemektedir. Çok katmanlı yapıya sahip olan gerçeklik seyirciler tarafından bulunmalıdır. Bazin, önemli olanın uzamsal gerçeklik olduğunu öne sürmektedir. Görüntüde yer alan hayali nesneler gerçeklik yanılsamasını yok etmemektedir çünkü sinema gerçeklik 
yanılsamasını uzam ile sağlamaktadır (Andrew, 2010: 229). Görüntüde var olan nesneler sinemasal zaman ve mekân içerisinde var oldukları için gerçektirler. Dijital teknolojinin gelişmesini sinemanın yeniden doğuşu olarak nitelendiren William Brown'a (2013) göre yeni gelişen teknolojiler Bazin'in tüm sinema mitine doğru atılan önemli bir adımdır.

Sinemanın gerçeklik algısını nasıl yarattığı üzerine süregelen tartışmalar içerisinde biçimci ve gerçekçi yaklaşımla birlikte en önemli yaklaşımlardan birisi de sinemanın gerçeklik algısının bilişsel düzeyde nasıl işlediğini anlamlandırmaya çalışan önemli teorilerden birisi de aygit teorisidir. Baudry (1986), sinemanın seyircinin görüş alanının merkezinde yer alan ve bütünlük ve kontrol hissiyatı veren bir aygit olarak işlediğini ifade etmektedir, perde, karanlık oda ve salonun mekân sal olarak kurulumu Platon'un mağarasının anımsatan bir izleme deneyimi sunmaktadır. Seyirci ve perde arasındaki ilişkinin Lacan'ın imgesel evresinde var olan çocuğun ayna ile karşılaşmasındaki deneyimine benzeten Baudry sinemanın gerçeklik duygusunu henüz edinmemiş olan çocuğun ayna evresinde hissettiği efendiliğin bir benzerini ürettiğini öne sürmektedir. Sinema özneyi bakışın efendisi yaparak görüntünün sürekliliği ile gerçeklik yanılsaması yaratarak seyirciyi merkezi ve aşkın bir konuma yerleştirmektedir. Seyirciler sinemada film izleme eylemini karanlık bir salonda projeksiyondan yansıyan görüntülerin dikdörtgen bir perde üzerine düşürülmesi ile gerçekleştirmektedir (Elsaesser ve Hagener, 2014). Sinemada seyirci perdede yansıyan görüntüye tamamen güvenli bir mesafeden skopofilik bir bakışla filmi yönetmenin tercih ettiği çerçeve ve ölçeklerler şekillendirilmiş olarak izleme edimini gerçekleştirmektedir. Sanal gerçeklikte ise bu izleme edimi deneyimlemeye dönüşerek "seyirci" yi "kullanıcı"ya dönüştürmektedir. Uzamsal algının doğrudan mekân ve zaman içerisinde deneyimlenmesi ile sinemanın çok ötesine geçtiği bu deneyimde kullanıcılar sinemadaki çerçeve ve ölçek gibi yönetmen kontrolünden bağımsız bir şekilde içerikle buluşmaktadır. Etkileşimselliğin ön plana çıtığı sanal gerçeklik içeriklerinin belirlenmesinde kullanıcının özgürlügüünün sınırlarının ve niteliğinin ideolojik olarak tartışmalara açık bir parametre olduğunu söylemek gerekmektedir. Ancak bu durum sinemasal gerçeklik bağlamında var olan aygıt teorisi gibi bilişsel birtakım süreçleri ele alan teorilerin yeniden gözden geçirilmesi gerektiği gerçeğini değiştirmemektedir. Ağaoğlu Ercan (219: 122-124), sanal dünyayı fiziksel olandan ayıran ve fantazi dünyalara kaçış imkânı sunan bazı özellikleri şöyle belirtir: Bedensizleşme (sanal gerçeklikte kullanıcı hem bedensel olarak tüm duyu organları ile çerçevesiz bir dünyanın içine girer hem de fiziksel bedenin eksikliklerini tamamlama veya tamamen bedeni terk edebilme imkânına kavuşur), ölümsüzlük (sanal gerçeklikte doğum ve ölüm yoktur, simüle doğum ve ölüm olabilir; sanal gerçeklik ölümsüzlük vaadidir), zaman ve uzamın ortadan kalkması (sanal dünya mekânsal fiziki engellerden ve zaman kısıtlamalarından kurtularak eşzamanlı, akışkan ve oluş halinde yeni boyut sunmaktadır) ve kişinin kendilik değerini değiştirebilmesi (sanal maskenin içinde avatarlarla akışkan ve çoklu kimliklerle ekran kişiliğinin oluşturulması). Bu bağlamda sanallığın gerçekliği ya da gerçek olmaması felsefi temel bir sorun olarak karşımıza çıkar. "Sanal ortamlar ve dijital alan genel olarak ontolojik karışıklık yaratır ve gerçeklik ile kurmaca, hakikat ve gerçek dışılık arasındaki sınırları çizmemize ve yeniden çizmemize neden olur." (Brey, 2014:53). Dolayısıyla fiziksel varlıklar sanal bir ortamda ontolojik olarak çoğaltılamazlar ancak sanal formları birer simülasyon veya temsil olabilirler. 


\section{Sanal Gerçeklik ve Dijital Oyun İlişkisi}

Sherman ve Craig (2019: 8), sanal gerçekliği alternatif bir gerçekliği veya öznel bakışı sarmalayan (immersiyon) ${ }^{6}$ bir ortam olarak açılamaktadır. Farklı bir sarmalayan gerçekliğe girme veya öznel bakışa girme, aracın katılımcılarına var olan dünyadan başka bir dünyaya giriş yapma veya var olan dünyayı başka birisinin gözünden görme imkânı vermesi anlamına gelmektedir. Kullanıcıya sanal dünyada olma yanılsaması yaratan şey, kullanıcıyı ses ve görüntü ile kuşatarak orada olmaya, nesnelerle ilişkiye girerek sanal dünyanın kendisini çevrelediğini hissetmesini sağlayarak inandırabilmesidir. Bu alternatif dünya gerçekte var olan ancak başka bir yerde olan bir mekân veya çoğunlukla roman yazarları, bestekârlar, sanatçılar ya da yaratıcı bireylerin zihinlerinde yarattıkları mekânlardan oluşmaktadır. Sanatçıların, yazarların veya yaratıcı zihinlerin ürünleri olan sanal gerçeklik içerikleri doğası gereği dijital dünyanın birer ürünü olarak karşımıza çıkmaktadır. Dijital dünyada hikâye anlatma ve sanal gerçeklik kavramları bir araya geldiğinde ise karşımıza çıkan kavramın "dijital oyun" olduğunu söylemek yanlış olmayacaktır, çünkü zaten sanal gerçeklik teknolojisinin temelinde yatan etkileşim ve üretim mekanizmaları dijital oyun teknolojisi ile koşut bir şekilde gelişimini sürdürmektedir.

Sutton-Smith (1999: 68) oyunu biçimsel olmayan niteliklerinden yola çıkarak bulanık bir kavram olarak nitelendirmektedir; gündüz düşleri, rüyalar, festivaller, kurallı oyunlar, televizyonlar, video oyunları ve sanal gerçeklik gibi kavramlar farklı kültürlerde oyun tanımı içerisinde yer alabilmektedir. Oyun oynayan çocuklar kendi kurmaca evren ve kuralları içerisinde bir deneyim yaşayarak kendilerini gerçek dünyaya hazırlamaktadır. $\mathrm{Bu}$ noktadan bakıldığında oyun kavramının tarihinin insanlık ve kültür tarihinden eski olduğunu söylemek yanlış olmayacaktır, kültürel olarak tanımlaması yapılan oyun kavramı insan varlığını öngörmektedir, oysaki oynamak yalnızca insanlara özgü bir davranış değildir, hayvanlarda tıpkı insanlar gibi yetişme sürecinde oyunlar oynamakta ve bu yolla öğrenmektedir (Huizinga, 2018: 9-10). Huizinga oyunu belirli bir zaman ve mekân sinırları içerisinde özgür bir şekilde kabul edilen ve bağlayıcılığı olan kurallar çerçevesinde oynan, tek başına bir amacı olmayan ve gerilim, neşe gibi duygular uyandıran, sırdan hayattan farklı olduğu bilinci ile gerçekleştirilen gönüllü bir etkinlik olarak tanımlamaktadır (2018: 45). Sanal gerçeklik ve oyunun temel bağlarını Huizinga' nın tanımlamasındaki "sıradan hayattan farklı" ve "gerilim ve neşe" gibi duygular uyandırması nitelemelerinden hareketle kurabiliriz. Roberts, Arth ve Bush (1959: 597) oyunu kurallara dayalı anlaşma ile gerçekleştirilen bir faaliyet olarak ve Caillois (2006: 128) ise özgür, ayrışık (belirli bir mekân ve zamanda sınırlı), sonucu oyuncunun girişimlerine bırakılmış, kurallarla yönetilen ve gerçek yaşama karşı özgür bir gerçek sunan bir aktivite olarak tanımlamaktadır.

Dijital oyun kavramı, günümüzde yeni gelişen iletişim teknolojileri ile birlikte artık cep telefonları üzerinden milyonlarca oyuncunun online olarak gün içerisinde aktif katılım sağladıkları bir yapıya bürünmüştür. Cep telefonlarını gelişen işlem gücü ile mobil internet teknolojilerinde yaşanan dönüşümün getirdiği olanaklar her geçen gün daha fazla sayıda oyuncuyu online olarak dijital oyun oynamaktadır. Gonzalo Frasca (2001) dijital oyunu dijital bir yazılım üzerinden bir veya daha fazla kullanıcının karşılıklı ya da yapay zekaya karşı gerçekleştirdiği bir boş zaman etkinliği olarak tanımlamaktadır. Jesper Jull (2005) dijital oyunların kısıtlılık içermeyen bir boş zaman etkinliği olduğuna dikkat çekerken, Deterding, Khaled, Nacke ve Dixon (2011:8) ise dijital oyunu sonuçlara yönelik rekabet ve çekişme yaratan ve teknolojik araçlar vasıtası ile katılım sağlanan bir ortam olarak tanımlamaktadır.

6 İngilizcesi "immersion" olan kelime "batırma, daldırma, içerisine sokma" anlamına gelmektedir. Sanal gerçeklik teknolojisinde ise "sürükleyici, kapsamlayıcı, kapsayan, saran, sarmalayan, içerisine alan" gibi karşılıkları bulunmaktadır. 
Chris Crawford (2003: 137)'a göre dijital oyun ve oyuncu arasında dinleme, düşünme ve konuşma döngüsünde işleyen bir etkileşim vardır. Crawford'un bu ifadesinde yer verdiği etkileşim hem oyuncular hem de aktif olarak kendisini oyuncunun tercihlerine göre şekillendiren yapay zekâ temelli oyun arasında gerçekleşmektedir. Yani dijital oyunların etkileşimli yapısı hem oyuncu ile bilgisayar arasındaki hem de oyuncular arasındaki karşılıklı iletişim çerçevesinde şekillenmektedir. Dolayısıyla Manovich 'in (2001: 37-39) belirttiği gibi değişken yapıda kişiselleştirilebilen, dallanan yapılı ve etkileşimli bir yeni medya aracı olan sanal gerçeklik ve dijital oyun birbirlerine kökten bağlıdır. Dolayısı ile tüm oyunları birer sanal gerçeklik olarak görmek mümkündür.

Oyun ve sanal gerçekliğin kesiştiği nokta bir gerçeklik yaratılarak o gerçeklikle etkileşime geçerek bir deneyim yaşanmasıdır. Dünya üzerindeki mevcudiyetini ve hâkimiyetini kendi yarattığ ayna dünyalarda ${ }^{7}$ da sürdürmeye devam eden ve yarattığ 1 bu dünyaların (metaverse) ${ }^{8}$ tanrıları haline gelen insan her yeni gelişen teknoloji ile birlikte kendi zihninde kurduğu hikayesini daha gerçekçi bir şekilde aktarmanın yeni yollarını bulmaktadır. İşte bu yeni hikâye anlatı formlarından birisi olan sanal gerçeklik anlatısının yapısını ve işleyişi anlamlandırabilmek için var olan pratik ve teorik arka plandan hareket edip, dijital oyunun etkileşimli anlatısı ile bir araya getirmek gerekmektedir.

Sanal gerçeklik anlatısının yapısı diğer anlatı araçları ile birtakım benzerlikler göstermekle birlikte kendi anlatısı biricik kılan bazı özellikler sergilemektedir, aracın yapısı içeriğe ve biçime doğrudan etki etmektedir bu noktada sanal gerçeklik anlatısını diğer anlatı formlarından ayıran en önemli nokta onun etkileşimli yapısıdır (Aylet ve Louchart, 2003). Sanal gerçeklik anlatısının diğer yapılarla hem kesiştiği hem de ayrıştığı bir diğer nokta ise edebiyat, sinema ve tiyatro gibi diğer anlatılarda var olan yaratıcı merkezli bir hikâyeyi alımlayan "seyirci"nin yerini yine temelinde yaratıcısının belirlediği sınırlar içerisinde kısıtlı da olsa kendi özgür iradesi ile içeriği deneyimleyen "kullanıcı"nın almasıdır. Bu yapı içeriğin yaratım aşamasında kullanıcı odaklı olarak yaratılması gereksinimini doğurmaktadır ki bu durum sanal gerçeklik içeriklerini sinemadan çok dijital oyun içeriklerine yaklaştırmaktadır. Söz konusu olan dijital oyunlar olunca ortaya çıkan en önemli kavram dinamik hikâye anlatımıdır. Dinamik hikâye anlatımı ile geleneksel hikâye anlatımı arasındaki temel farklar ise dijital oyun anlatısının ve dolayısıyla da sanal gerçeklik anlatısının temelleri oluşturmaktadır.

Barthes (1993: 83) anlatının insanlık tarihi ile başladığını ve anlatısı olmayan bir halkın var olmadığını söylemektedir, anlatı tıpkı yaşam gibi hep var olagelmiştir. Richardson'a (1990: 118) göre anlatıda insanlar yaşamlarını ve deneyimlerini zamansal olarak anlamlı bir şekilde bölümleme ve organize etme süreçlerinden sonra bir sonuç çıkarak bir temsil tarzı ortaya koymaktadır ve insanlar dünyayı anlatısal olarak bir temsil tarzı şeklinde anlamlandırmaktadır. Arthur Asa Berger (1996: 4), ise anlatıyı belirli bir zaman ve mekânda geçen olaylar dizisinden oluşan öyküler olarak tanımlamaktadır. Bordwell ve Thompson (2008: 75), ise anlatının bir durum ile başladığını ve neden sonuç ilişkileri ekseninde birtakım değişimler geçirerek ve sonunda yeni bir durumun yer aldığını belirtmektedir.

Geleneksel ya da klasik sinema anlatısı izleyicisini olabildiğince fazla duygulandırma, ana karakter ile özdeşleştirme ve izleyici eyleme katma üzerine inşa edilmektedir. Bu anlatı yapısında sistem anlatımı görünmez kılma prensibi üzerine şekillenmektedir. Kameranın

\footnotetext{
7 Ayna Dünyalar (Mirror Worlds), David Gelertner tarafından 1993 yılında yazılan var olan gerçek dünyanın dijital teknolojiler ile birlikte sanal birer kopyasının çıkartılmasını ifade eden tanımlama, gerçek dünyanın sanal bir kopyasi.

${ }^{8}$ Gerçeğe yakın sanal dünya
} 
görünmez bir gözlemci olarak konumlandırılması ise anlatıcının görünmez kılınarak nesnel bir anlatım yanılsaması yaratılmaya çalışılır amaç izleyicinin filmin kurmaca olduğunu hissetmeden hikâye ile bütünleşerek olaylara tanık olduğu izlenimini edinmesidir. Duygusal olarak yönlendirilen izleyici film içerisinde doruğa ulaşan gerilimin çözüm kısminda sona ulaşması ile rahatlayarak arınma yaşamaktadır. Modern anlatılarda ise filmlerin belirli bir başı veya sonu yoktur. Filmler çoğunlukla günlük yaşamdan alınan bir kesit ile başlar ve biter. Filmin sınırları içerisinde olayların başı ve sonu yoktur, izleyici bunları düşünmeye sevk edilmeye çalışılır. Filmin başını ve sonunu düşünerek anlamlandırmaya çalışan seyirci salonda kendisini koltuğunda güvende hissedeceği yerde tedirgin ve tamamlanmamışlık hissi içerisinde salondan ayrılmaktadır (Gürkan ve Ozan, 2014: 157-160). Dolayısı ile dijital oyun anlatısının kendi içerisinde birtakım özellikleri klasik sinema anlatısı ile ve de klasik dramın bileşenleri ile kesişmekle birlikte bazı özellikleri ise izleyiciyi düşünmeye sevk etme, kendini güvende hissetmeme gibi bazı özellikleri ise modern anlatı kodları ile kesişmektedir.

\begin{tabular}{|c|c|c|}
\hline \multicolumn{3}{|c|}{$\begin{array}{l}\text { Dramin Sinema } \\
\text { Oyun Bileşenleri }\end{array}$} \\
\hline $\begin{array}{l}\text { Mimesis } \\
\text {, katarsis }\end{array}$ & $\begin{array}{l}\text { Yaşamın taklidi } \\
\text { / yeniden } \\
\text { yaratılması ve } \\
\text { öyküde arınma }\end{array}$ & Yaşamın taklidi, öykünün içinde / dışında arınma \\
\hline $\begin{array}{l}\text { Karakter ve } \\
\text { özdeşleşme }\end{array}$ & $\begin{array}{l}\text { İzleyicinin eylem } \\
\text { halindeki kişi ile } \\
\text { özdeşleşmesi }\end{array}$ & $\begin{array}{l}\text { İzleyicinin eylem halindeki kişi ile özdeşleşmesi + } \\
\text { oyuncunun kişinin yerine geçerek ulaştığ1 özdeşleşme }\end{array}$ \\
\hline $\begin{array}{l}\text { Eylem ve } \\
\text { mücadele }\end{array}$ & $\begin{array}{l}\text { Eylem ve } \\
\text { mücadeleyi } \\
\text { izleyici } \\
\text { özdeşleşmesi } \\
\text { yoluyla } \\
\text { deneyimleme }\end{array}$ & $\begin{array}{l}\text { Hem izleyerek hem de fiziksel-reel eylem ile mücadeleye } \\
\text { girme }\end{array}$ \\
\hline $\begin{array}{l}\text { Diyalekti } \\
\text { k gelişim } \\
\text { neden- } \\
\text { sonuç } \\
\text { ilişkis } \\
\text { i }\end{array}$ & $\begin{array}{l}\text { Öyküde, } \\
\text { mantıksal } \\
\text { sözdizimi } \\
\text { sağlamaya } \\
\text { yönelik } \\
\text { diyalektik } \\
\text { mantık }\end{array}$ & $\begin{array}{l}\text { Öykü veya eylem bütünlüğünde diyalektik mantıkta } \\
\text { sözdizimi veya olasılıklar mantığı }\end{array}$ \\
\hline
\end{tabular}

Tablo 1: Dramatik yapı bileşenlerinin karşılaştırması (Sayılgan, 2015).

Dijital oyunların anlatı yapısı oyunların teknik yapısı dolayısı ile etkileşimli ve dinamik yapıdadır, yani çoğunlukla kullanıcıların eylemleri doğrultusunda hikâyenin akışı yönlendirilmektedir. Dinamik hikâye anlatımında önceden tanımlanmış bir sırada ilerlemeyen bir öykü deneyimi söz konusudur. Her yeni kullanıcı farklı yollar aracılığı ile içeriği aktif olarak keşfetmekte ve deneyimlemektedir (Marconi ve Nakagawa, 2017). Belirli bir standardı olmayan bu yapıyı geleneksel anlatıdan ayıran temel nokta, sonucu, yazarın değil oyuncunun eylemlerinin belirlemesidir (Yengin, 2012: 111). Sinemaya göre daha karmaşık bir yapıya sahip olan dijital oyunlarda oyuncuların bu karmaşık ve dinamik yapıya ayak uydurması gerekmektedir. 


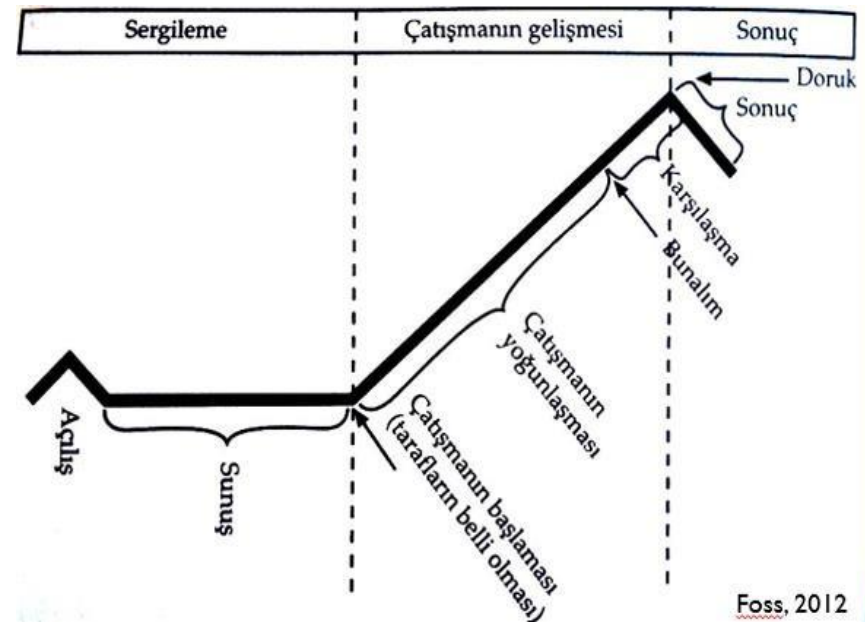

Hikaye anlatma Modelleri

Geleneksel

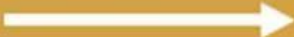

Görsel 1: Geleneksel hikâye anlatımı akışı ve dinamik hikaye anlatımı karşılaştırması (Foss, 2012: 162, Marconi ve Nakagawa, 2017: 5)

Geleneksel hikâye anlatımında ve sinemada sergileme, çatışmanın gelişmesi ve sonuç şeklinde ilerleyen yapı, dinamik yapıda her biri kendi içerisinde bir anlatısı olan farklı yolların bir araya gelmesi ve bu yollardan hangisinin izlenerek sonuca ulaşılacağına kullanıcının karar vermesi ile devam eden bir yapıya sahiptir. Bu doğrultuda bakıldığında dijital oyunların dinamik anlatı yapısının kodları ile klasik anlatı sinemasının bazı temel kodlarının kesişiminden faydalanarak bir okuma yapmak sanal gerçeklik anlatısını anlamlandırabilmek adına önemli olarak görülmektedir.

\section{Trinity VR ve Selyatağı VR Örnekleri}

International Data Corporation verilerine göre sanal gerçeklik ve arttırılmış gerçekliğin market payı 2016 yılında 6,1 milyar dolar iken bu rakamın 2020 yılında yaklaşık 143,3 milyar dolar civarında olacağı tahmin edilmektedir (Bang ve Yıldırım, 2018). 2019 yılında ise tüketicilerin harcama hacimleri sanal gerçeklik oyunlarına 4 milyar dolar, etkileşimli video benzeri içeriklere 2 milyar dolar, arttırılmış gerçeklik oyunlarına ise 606 milyon dolar olan payın dağılımı belirleyeceği öngörülmektedir (Framingham, 2018). 2025 yılına gelindiğinde ise yaklaşık 35 milyar dolar hacme ulaşması beklenen sanal ve arttırılmış gerçeklik pazar verilerinde 18,9 milyar dolarlık bölümünü tüketiciye yönelik içeriklerin oluşturması ve bu içerikler içerisinde de video oyunlarının payının 11,6 milyar dolar olması beklenmektedir (Probst, Pedersen ve Dakkak, 2017: 4). Bu verilerden yola çıkarak sanal gerçeklik içeriklerinin geleceğinde en büyük payın yine şu anda olduğun gibi tam etkileşimli dijital oyunlara ait olacağını görmek mümkündür, bu durum sanal gerçeklik teknolojisinin yapısı gereği sahip olduğu etkileşimi yaratmanın en azından şu an için mümkün olan tek yolunun oyun motoru aracılığı ile yapılabilmesinden kaynaklanmaktadır. Buradan hareketle bu çalışmada örneklem olarak seçilen yapımların belirlenmesinde oyun motoru kullanılmış olan veya 360 derece video olarak kayıt edilmiş olan içerikler arasından bir seçim yapılmıştır. Trinity VR (2018) örneği arkasında Universal gibi küresel sinema endüstrisinin en güçlü şirketlerinden birinin desteği ile üretilmiş olan ve günümüzde en popüler dijital oyun marketi olan Steam platformu üzerinden satışa sunulmuş büyük bütçeli ve ana akım örnek olarak alınmıştır. Selyatağı VR (2018) filmi ise Emre Yeksan'ın Yuva (2018) filminin senaryosundan hareketle birçok festivalde gösterilmiş ve sanal gerçeklik filmleri çeken Deniz Tortum ${ }^{9}$ yönetmenliğinde hazırlanmış olan yerli ve bağımsız bir sanal gerçeklik filmi olarak seçilmiştir.

\footnotetext{
${ }^{9}$ Bkz. https:/ / deniztortum.com/
} 


\section{Trinity VR: Etkileşimli Sanal Gerçeklik Deneyimi}

Trinity VR filmi Unlimited şirketi tarafından Universal'ın desteği ile Patrick Boivin yönetmenliğinde 2018 yılında hazırlanmış bir sanal gerçeklik deneyimidir. Filmin tanımlarında içerik "etkileşimli sanal gerçeklik deneyimi" ve "büyük bütçeli film macerasında canlı karakterler ile etkileşime geç"10 ifadeleri kullanılmış ve filmin resmi tanıtım videosunda ${ }^{11}$ ise "resmi oynanış tanıtımı" (official gameplay trailer) ifadelerine yer verildiği görülmektedir. Filmi tanımlamak için kullanılan ifadelerden ve tanıtım videosundan bazı bölümlerinde oyun motoru aracılığı ile etkileşim sağlandığ1 anlaşılmaktadır. 10 dakikalık bir süreye sahip olan içerik yapımcı John Hamilton' un (2018) ifadesi ile toplamda 5 parçadan oluşacak olan serinin ilk parçası olarak tasarlanmıştır. Filmde post apokaliptik bir gelecekte artık insanların var olmadığı ve yapay zekânın tüm dünyayı ele geçirdiği bir dünyada son kalan androidlerin yapay zekâ ile olan mücadelesi deneyimlenmektedir. Bir androidin gözünden deneyimlenen hikâyede kimi zaman yaralanan ve baygınlık geçiren kullanıcı yapay zekanın yarattığı arafta kendisini bulmaktadır. $\mathrm{Bu}$ araf aslında filmin üretim aşamasında toplanan hacimsel (volumetric) görüntüden oluşmakta ve senaryoya entegre edilmiş olarak görünmektedir. Hamilton (2018), Trinity VR ile ilk etkileşimli sanal gerçeklik kurmaca filmini yaratmak, teknik ve yaratımın sınırlarını zorlamak, büyük bir sanal gerçeklik filmi deneyimi sunmak, yüksek çözünürlük ve kalitede içerik üretmek, sanal gerçeklik anlatısının dilini geliştirmek, geleceğin sanal gerçeklik içerikleri için etkileşimli sanal gerçeklik hikâyesi inşa etmek istediklerini ifade etmiştir. Yapım, toplamda 20 ayda ve 1,5 milyon dolar bütçe ile hazırlanmıştır.

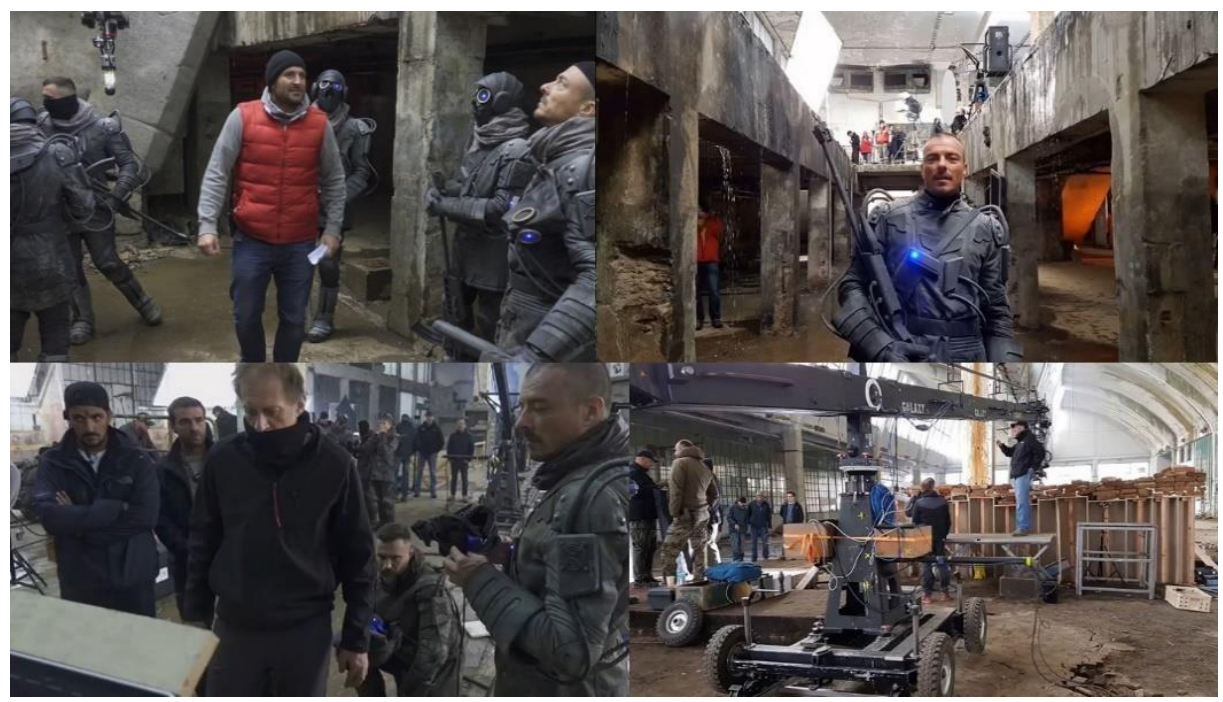

Görsel 2: Trinity VR Kamera Arkası Görüntüleri (Unite Berlin, 2018)

Hamilton (2018) içeriği hazırlarken karşılaştıkları zorlukları şu şekilde sıralamaktadır: dinamik 360 video sekansları yaratmak, canlı videoda etkileşim sağlamak, sinematik geçişler yaratmak. Tüm bu engelleri aşmak için içerik üretilirken 360 derece kayıt alan kameranın yanında point cloud teknolojisi ile mekânın ve aksiyonun hacimsel kaydı çıkartılarak tüm aksiyonun 3 boyutlu bir kopyası yaratılmıştır. Yönetmen sete ve aksiyona hâkimiyetini arttırmak adına filmdeki karakterlerden birisini canlandırarak sette aktif olarak var olmuştur. Hacimsel kayıt olarak alınan zahiri 3 boyutlu görüntüler senaryo içerisine entegre edilerek sinematik bir geçiş efekti olarak kullanılmıştır. Yani elde edilen hacimsel veri çekimler sonrasında senaryoya entegre edilerek kurgu aşamasında planlar arasındaki

${ }^{10}$ Bkz. https://www.eyeoncanada.ca/digital-media/details/trinity

${ }^{11} \mathrm{Bkz}$. https://www.youtube.com/watch?v=oK46XJq1I4o 
kesintisiz geçişi sağlamak için kullanılmıştır. Nuke, Maya ve Adobe After Effects programları ile görsel efektler yaratılmış ve toplanan tüm bu veriler Unity oyun motoru içerisinde bir araya getirilerek içerik üretilmiştir.

\section{Trinity VR Filminin Analizi}

\section{Anlatı}

Anlatı yapısı tek bir hikâye üzerine geriye dönüş ve ileriye atlama üzerine kurulu nonlineer bir akış izlemektedir. Öznel bakış açısından kurgulanan anlatıda kullanıcı, hikâyenin içerisindeki karakterlerden birisi olarak konumlandırılmıştır. Kullanıcının hikâyeye adapte olabilmesi için açılışta bir giriş metni ile başlar. Hikâyede insanlığın yarattığı bir yapay zekâ kodunun kendini geliştirerek önce insanlığı daha sonrasında ise kendi yarattığ androidlerin yok etme ve tekilliğe ulaşma mücadelesini anlatılmaktadır. Hikâyenin zihinde oturtulması için geriye dönüşler ve ileriye atlamalar arasında diyaloglara ve kilit birtakım cümlelere yer verildiği görülmektedir. Vurulan bir androidin dijital evrene yani kodlar sistemine geçer. Bu sistemin içerisinde tekillik olan yapay zekâ ile bütünleşir ve bir veriye dönüştüğü gösterilir. Hikâyenin sonunda tekilliğin yarattığı bir robotla savaşan androidlerin savaşı o an için kazandığı görülür. Ancak öldürülen robotunda veriye dönüştüğ̈̈ sırada androidlerin arasından birisine geçiş yaptığı gösterilir, yani tekillik aslında androidlerin zaten arasına sizmıştır.

\section{Mizansen}

Hikâyenin mizansenleri oluşturulurken eski bir tank fabrikasında gerçek mekânda çekimler yapılmış aynı zamanda da bu mekânın volumetrik olarak 3 boyutlu bir kopyası da çıkartılmıştır. Ayrıca tekilliğin ana merkezi olarak tasarlanan mekân olarak ise Ayasofya'nın volumetrik bir kopyası çıkartılmıştır. Mizansen içerisinde patlama efektleri, ateşler, yağmur damlaları gibi öğeler dijital olarak eklenmiştir. Mekânın kaydı alınırken tavan kısmında 1şıklandırma sistemi kullanıldığı için çatı yerine açık gökyüzü ve etkileşimli olarak kullanıcının yüzüne damlayan yağmurlar CGI olarak eklenmiştir. Mizansen içerisindeki aksiyonlar oyuncu hareketleri, sabit kamera açıları ve kamera kaydırma hareketleri ile sağlanmıştır. Kullanıcının hikâyeyi aktif olarak takip edebilmesi adına mizansen içeresinde oyuncu hareketleri ve ses efektleri bir arada kullanılmıştır.

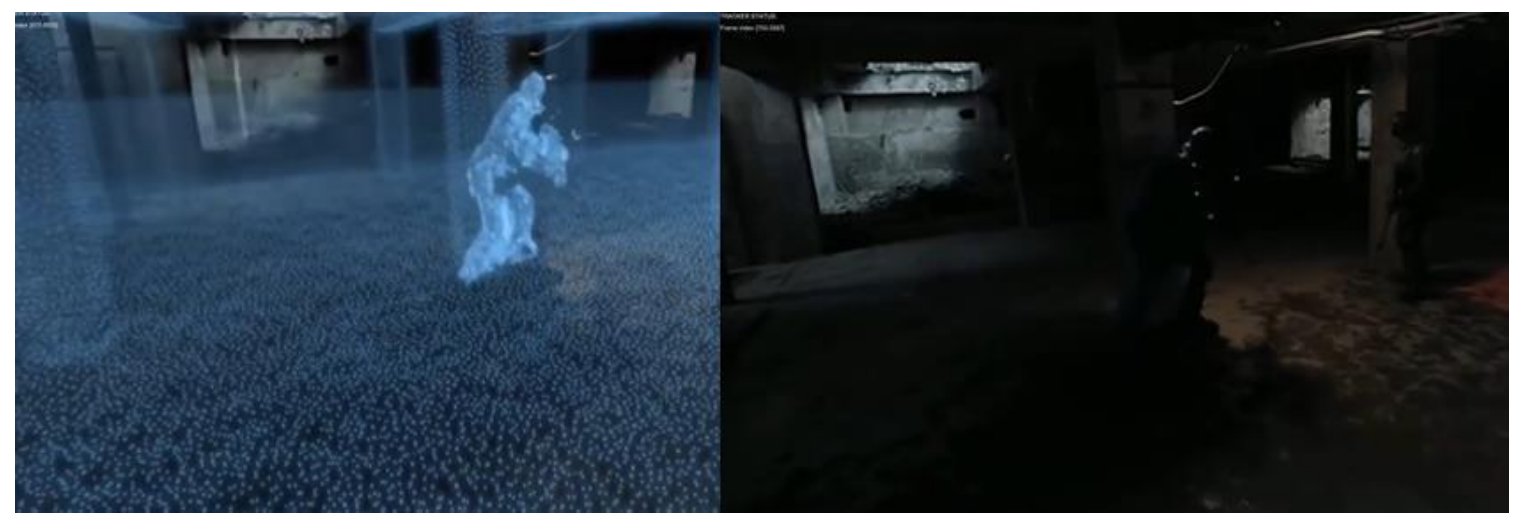

Görsel 3: Trinity VR Hacimsel ve Gerçek Kaydın Eşleştirilmesi (Unite Berlin, 2018)

\section{Sinematografi}

Yapımda on iki adet sabit kamera, dört adet hareketli plan sekans ve aralarda hacimsel (volumetrik) verilerin geçiş olarak kullanıldığı bir form oluşturulmuştur. Kamera hareketleri ve kameranın bakış açısı filmin başından sonuna kadar öznel bakış (point of view) olarak tasarlanmıştır. Geleneksel sinemada görmeye alışık olduğumuz herhangi bir kamera 
hareketi bulunmayan içerikte kullanıcının istediği noktaya bakma özgürlüğü bulunmaktadır ancak hikâyenin odak noktasına yönlendirme için ses ve efektler kullanılmıştır. Kullanıcın içeriğe ve akışa müdahale etmesini sağlayacak şekilde hikâye içerisinde özgürleşebilmesi şu anki teknoloji ile ancak oyun motorları aracılığı ile sağlanabilmektedir. Dolayısı ile bu tür uygulamalar, sanal gerçeklik içeriklerini bir filmden çok bir oyuna yaklaştırmaktadır. Işıklandırma için doğal ş̧ık ve özellikle de tavanın olmadığı mekânlarda yapay aydınlatma ekipmanları bir arada kullanılmıştır. Yapay aydınlatmanın kullanıldığı planlarda daha sonrasında CGI ile çatı ve gökyüzü gibi eklemeler yapılmıştır.

\section{Kurgu}

Trinity $V R$, non-lineer bir akış içerisinde geriye dönüşler ve ileriye atlamalar şeklinde kurgulanmıştır. Sanal gerçeklik anlatısında kullanıcıların hikâyeye adaptasyonun kolaylaştırılabilmesi adına hızlı kesme çok tercih edilen geçişler olarak görülmemektedir. Yalnızca üç adet hızlı kesme yapılmıştır. Hikâyenin kalan kısmında on adet kararma açılma, yedi adet hacimsel veri ve bir adet beyaza düşme ile planlar arasında geçiş sağlanmıştır. Hikâyenin başında bir açılış metni bulunmakta ve geleneksel sinemada hikâyedeki aksiyonun yukarı doğru tırmandığı bölüme kadar olan ilk bölümde kararma açılma efekti ile yumuşak geçişlere yer verilmiştir. Çekimler sırasında gerçek zamanlı olarak kaydedilen 3 boyutlu hacimsel veri kurgu aşamasında senaryoya entegre edilmiş ve hacimsel görüntüler androidlerin dijital evreni olarak tasarlanarak planlar arasındaki geçişlerin kesintisiz bir şekilde yapılmasına olanak sağlamıştır. Aksiyonun tepe yaptığı ve düğüm noktasında ise iki plan arasındaki geçişlerde gerçeklik etkisinin kopmaması ve kullanıcın ilgisinin hikâyede tutulması için hacimsel olarak elde edilen veri geçiş efekti olarak kullanılmıştır. Bu yolla hikâye kesilmeden akmaya devam etmektedir, bir anlamda invisible cut (görünmeyen kesme) yapılmıştır. Karakterin (kullanıcının) vurulduğu sahne de ise beyaza düşme ile geçiş yapılmıştır. Film kurgulanırken hacimsel veri ile karakterler ve diyaloglar yeşil perde önünde ayrı ayrı çekilerek eklenmiştir. Gerçek mekânlarda yapılan çekimlerde ise mekân ve aksiyon 360 derece ve stereoskopik olarak kayıt altına alınırken ekstra ekipmanlar ile mekânın ve aksiyonun volumetrik kopyası alınmış ve kurguda üst üste bindirilerek derinlik ve üç boyut hissiyatı elde edilmiştir. Patlama efektleri, yansımalar, yanan ateşler ve gökyüzünden düşen yağmur damlaları gibi CGI efektler ise Nuke, Adobe After Effects, Maya ve Unity yazılımlarının kombine olarak kullanılması ile bir araya getirilmiştir.

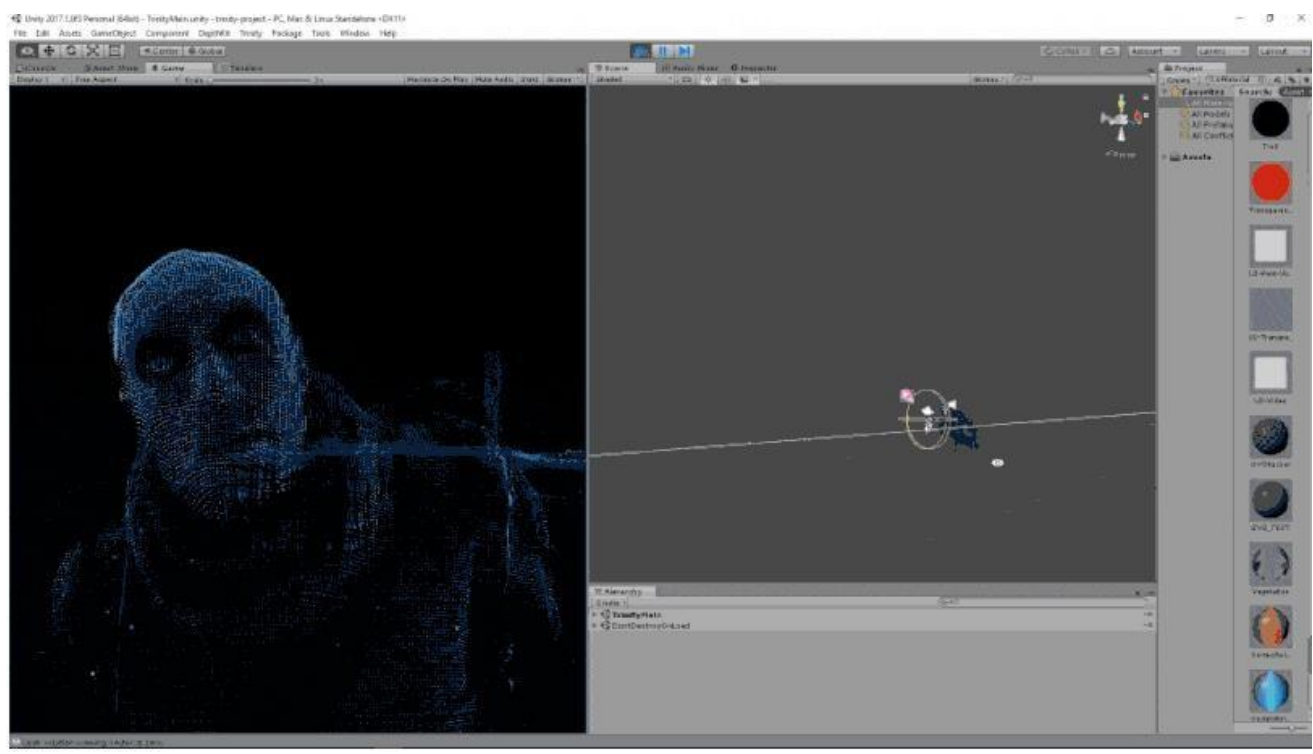

Görsel 4: Trinity VR Unity Motoru İle 3 Boyutlu Kurgu (Unite Berlin, 2018) 


\section{Ses}

Trinity VR filminde diyalog, mekânsal ses, dış ses ve özel ses efektleri gibi geleneksel sinemanın kullandığ1 tüm ögelerden faydalanıldığı görülmektedir. Aradaki fark sesin 360 derece olarak kaydedilmesi, kurgulanması ve mekâna özel olarak 360 derece ve derinlikli olarak üretilmesidir. Üretim aşamasında mekânın akustiği de dâhil olmak üzere detaylı bir çalışma yapıldığı görülmektedir. Kullanıcının odağının yönlendirilebilmesi adına hikâyenin akışı sırasında ses ve diyaloglar ile yönlendirilme yapıldığı görülmektedir.

\section{Orada olma Hissi (telepresence)}

Trinity VR yapımında "orada olma hissi" tanıklık ve etkileşimin sağlanabilmesi için bazı sahneler öne çıkmaktadır. Kullanıcının sanal ortamı deneyimleyebilmesi için öznel bakışta çatışma sahnelerinden birisinde mermilerden kaçma imkânı (sınırlı bir şekilde ve oyun motoru ile), plan sekans içerisinde ayna karşısında gelindiğinde kendisini ayna görme ve baş hareketlerini takip edebilme ve başını yukarı kaldırdığında karakterin kaskına düşen CGI ile hazırlanmış yağmur damlaları kullanılmıştır. Trinity VR yapımının bu noktada "orada olma hissi"ni yaratabilmek adına kullanıcıya tam 6 DoF12 hareket özgürlüğü vermediği için bu hissi yaratabilmek için öznel kamera, ayna ve yağmur damlası ve 360 derece ses kaydı gibi detayların yerinde kullanıldığını söylemek mümkündür.

\section{Selyatağı VR: 360 derece sanal gerçeklik deneyimi}

Selyatağı VR ${ }^{13}$ filmi aslında yönetmeni Deniz Tortum'un (2019) ifadesi ile 360 derece bir video formatında hazırlanmış bir filmdir. 13 dakikalık bir deneyim sunan filmin yapımcısı Emre Yeksan'ın Yuva (2018) filminin de yapımcısı olan Anna Maria Aslanoğlu. Film Yuva filminde kendisini ormana kapatarak betonarme dünyadan kaçan Veysel'in öyküsünü ormanın gözünden izlemeyi sağlamaktadır. Ormanda yaşanan yıkımın ağaçların gözünden deneyimlendiği içerikte zincirleme geçişleri, 1şık ve ses ile izleyicinin odağını yönlendirme, bazı görsel efektler ile hikâye farklı bir akstan anlatılarak Yuva filminin evrenini genişletmek amacı ile tasarlanmıştır. Deniz Tortum (2019) filmin yaratım aşamasında karşılaşılan zorlukları şu şekilde sıralamıştır:

Çerçeve olmadığı için mizanseni nasıl kurduğunuz çok önemli, seyircinin nereye bakacağını ayarlamak farklı bir zorluk olarak öne çıkıyor, oyuncu yönetimi kaydı başlattıktan sonra arabanın arkasından sesleri dinleyerek yapmak gerekti. Mekânda ses kaydı alındı ancak ses için ekstra post prodüksiyon yapıldı bu özel bir uzmanlık gerektiriyor.

\footnotetext{
${ }^{12}$ Üç boyutlu uzayda katı bir cismin hareket özgürlüğünü ifade eder. Özellikle, vücut üç dikey eksende ileri / geri (dalgalanma), yukarı / aşağı (yükselme), sol / sağ (sallanma) çeviri olarak pozisyon değiştirmekte serbesttir, genellikle üç dikey eksende dönme yönündeki değişikliklerle birleştirilir. Sapma (normal eksen), eğim (enine eksen) ve rulo (uzunlamasına eksen)

${ }^{13} \mathrm{https}$ // / www.youtube.com/watch?v=hF15I8_2P2M
} 


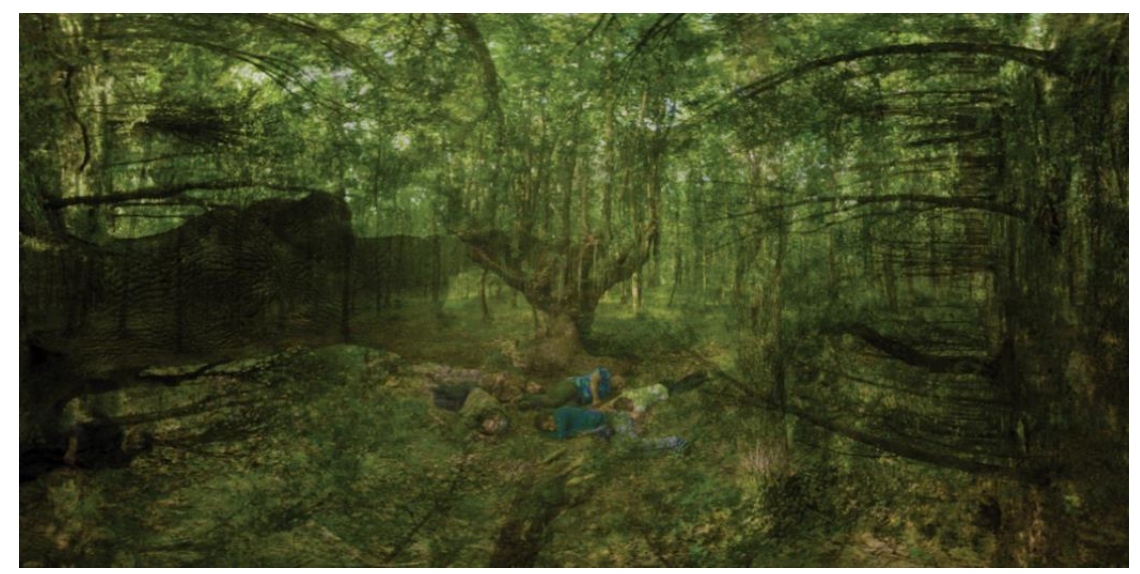

Görsel 5: Selyatağı VR Filminden bir kare (Tortum, 2019)

Yuva filminin yönetmeni Emre Yeksan (2019) ise Selyată̆ı VR filmi üzerinden sanal gerçeklik anlatısına ilişkin fikirlerini şu şekilde ifade etmektedir:

Art alan olmadığı için sürekli olarak bir şeyleri saklamak gerekiyor, tek seferde çekmek gerekiyor, aksiyon içerisinde hareketle veya mekânsal ses ile seyircinin bakışını yönetmek gerekiyor çünkü sinema dilinin çok ciddi bir öğesi olan çerçeve burada yok ve yönetmenin müdahalesi kısitlı. Görüntü ve ses prodüksiyonu sinemaya göre daha ağır. Boom kullanılamıyor, görsel efektsiz çalışmak çok zor en azından bazı şeyleri sonradan silmek gerekiyor görüntüden. Çekim ölçeği olmadığı için karakterlerin mizansen içerisindeki hareketleri ile ölçekleri ayarlamak gerekti. Filmi 180 derecelik iki parça halinde çekip birleştirmek mümkün fakat yine post prodüksiyonda ve sahne içi mizansende özel ayarlamalar yapmak gerekiyor. Plan-sekansa uygun bir senaryo ile tek seferde çekilmesi gerekiyor. Geleneksel sinemadaki zamansallık kavramı sanal gerçeklik için de mümkün, üst üste bindirme gibi geçiş efektleri kullanılabiliyor hikâyeye uygun bir şekilde. Yeniden bir dil kurmak gerekiyor, sanal gerçeklik geliştiren ya da genişleten bir format değil de kendi başına yeniden bir görsel dil yaratan bir format olacak.

\section{Selyatağı VR Filminin Analizi}

\section{Anlati}

Hikâyenin anlatısı lineer bir akış üzerine sıralı olarak yaşanan olayların gösterilmesi üzerine kurulmuş bir yapıdadır. Yuva filminden hareketle hazırlanan hikâyede kendisini yok etmeye gelen işçilere karşı bir ağaç ve onun üzerinden ormanın verdiği kendi mücadelesini seyirci kenardan gözlemci olarak deneyimlemektedir. Hikâyede ormandaki ağaçların kesilmesi için köyün boşaltılması ve ormanda kesilecek ağaçların belirlenmesi sırasında etrafta dolaşan polis ve çalışan işçiler işlerini ağırdan alarak yapmaktayken ormandaki en yaşlı ağacın kendi önlemini alarak tüm insanları bayıltarak kendisini bu yıkımdan koruması anlatılmaktadır.

\section{Mizansen}

Hikâyede mizansenler gerçek mekânlarda, gerçek oyuncular ve objeler ile tasarlanmıştır. Mizansen içerisinde seyirci oyuncu aksiyonları ve sesler ile yönlendirilmektedir. Seyircinin istediği noktaya bakma özgürlüğü bulunduğundan ana karakterlerin konuşmaları, çıkardıkları sesler ile seyircinin odağı yönlendirilmektedir. Ağacın ses çıkarak konuştuğu noktalarda giren altyazı ve filmin genelinde bulunan diyalogların altyazılarının bulunduğu açı da kullanıcının nereye bakması gerektiğini göstermektedir. Olay örgüsü içerisinde mizansenler plan sekans olarak tasarlanmış ve aksiyon plan içerisindeki oyuncu hareketleri ile sağlanmaktadır. 


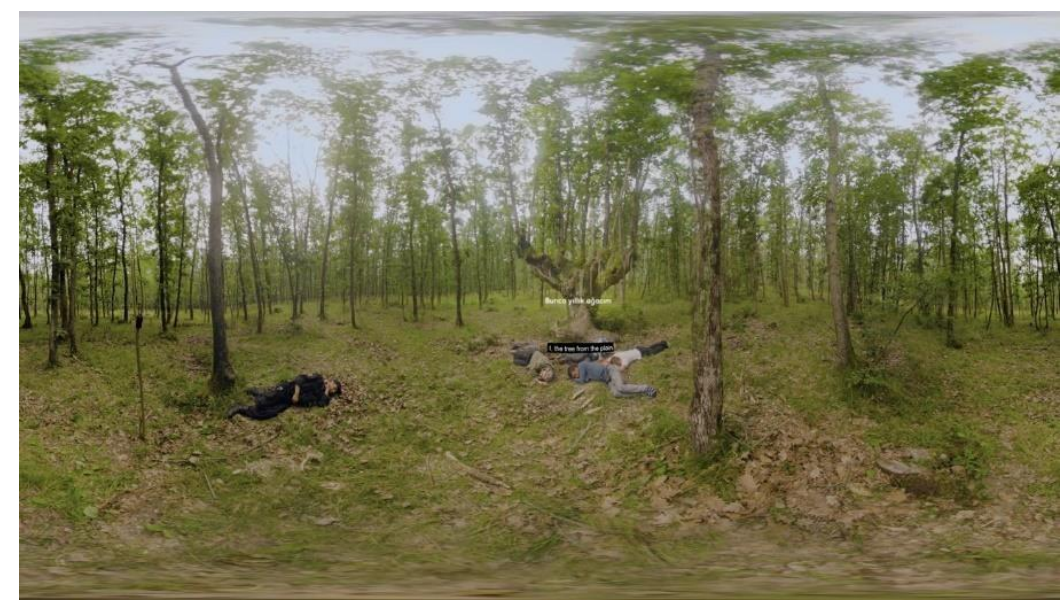

Görsel 6: Selyatağı VR filminde ağacın konuştuğu plandan bir kare (Tortum, 2019)

\section{Sinematografi}

Üç adet dijital aynasız kameranın ayrı ayrı aldığı kayıtlar ile tepe ve dip noktalarda ise 360 derece bir kameranın kayıt alması yolu ile yapılan sabit çekimler bir araya getirilerek 360 derece bir görüntü elde edilmiştir. Seyirci ormanda geçen olaylara dişardan tanık olmaktadır. Hikâyenin tamamı sabit kamera ile çekilmiştir. Herhangi bir kamera hareketi söz konusu değildir. Yalnızca izleyici kendi istediği noktaya bakma özgürlüğüne sahiptir. Sinemadaki kamera hareketleri veya çekim ölçekleri sanal gerçeklik filmlerinde var olmadığından yakın planda çekilmesi gereken noktalarda oyuncuların kameraya doğru yaklaşması yolu ile sabit 360 derece plan içerisinde yakın plan yapıldığı görülmektedir. Aksiyon içerisinde doğrudan akış ile ilgisi olmayan diğer hareketler ise kameraya uzak noktada uzak planda görülmektedir.

\section{Kurgu}

Hikâye tamamen siyah üzerinde seslerin gelmesi ile başlamaktadır. Bu açılış planında ormanda karanlıkta el feneri ile Veysel'i arayan kişiler görülmektedir. Seyirci el fenerlerinin 1şığı ve ses ile yönlendirilmektedir. Yine seyircinin bakmasının beklendiği açılarda bulunan altyazılar yönetmenin seyirciyi nereye yönlendirmek istediğine dair bir kanıt sunmaktadır. Karanlık ormandan köy meydanına geçişte zincirleme kullanılmaktadır. Filmin kalan kısmında kesme kullanıldığı görülmektedir. Genel olarak mizansen içi aksiyonların hızlı ve hareketli bir yapısı olmaması ve plan değiştirildiğinde seyirciye kendi yönünü bulmasını sağlayacak kadar zaman tanıacak şekilde plan uzunluğunun tasarlanması ile kesme geçişlerin hikâyenin takibinde bir engel olmadığı görülmektedir. Ormanın kendisini korumak için uğultu çıkararak etrafındaki insanları bayılttı̆̆ı planlar arasında geçişlerde kesme yapılmıştır. Planlar arası devamlılık ses kuşağının sürekliliği (Uğultu sesi devam etmektedir.) ile sağlanmıştır. Açılıştaki karanlık orman planında gökyüzündeki ışıklar ve parıltılar ile ormandaki ağacın konuştuğu ve etrafındakileri bayılttığı planlarda görsel efektler kullanılmıştır. Planlar arasında geçişler yapılırken bir önceki planda izleyicinin nereye bakması gerekiyor ise diğer planda da ilk açılışta aksiyonun odağı o noktaya yerleştirilerek izleyicinin devamlılığı takip etmesi kolaylaştırılmıştır. Sanal gerçeklik filmlerinin kurgulanması sırasında karşılaşılan en önemli sorunlardan birisi olan seyircinin bakış yönünü tahmin edebilmesi sorunu, bu yapımda aksiyonun doğru yerleştirilmesi ile çözülmüştür. Filmin tamamı gerçek mekânlarda doğal 1şık ile çekilmiştir. 


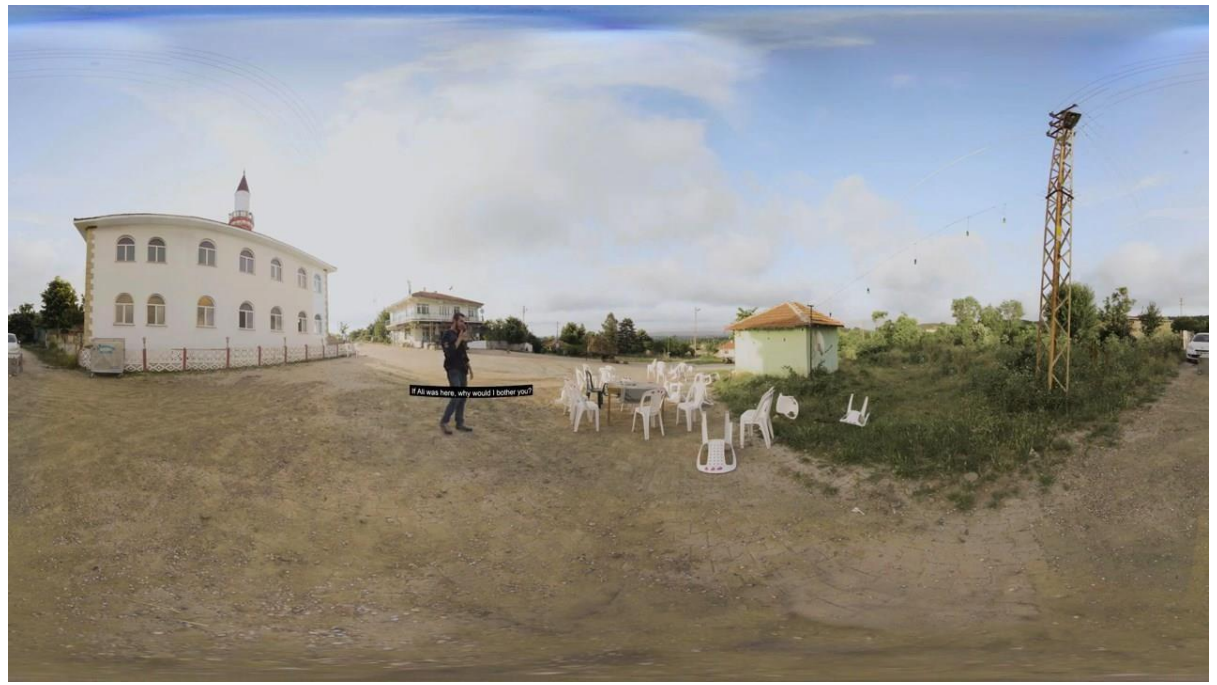

Görsel 7: Selyatağı VR filminden doğal mekanda gündüz çekilen plandan bir kare (Tortum, 2019).

\section{Ses}

Selyatağı VR anlatısının en önemli unsurlarından birisi ses olarak görülmektedir.

Planlar arası devamlılığın ses ile yapılması, seyircinin yönlendirilmesinde sesin kullanılması, plan içerisindeki aksiyonlarda sesin doğru yönlendirilmesi ve ortam seslerinin 360 derece olarak kayıt edilmesi mekânı ve hikâyeyi hissetmek konusunda önemli işlev görmektedir. Kuş sesi ve diğer bazı doğa seslerinin yapay olarak eklenmiş olduğu belirtilmekle birlikte 360 derece olarak başarılı bir şekilde kurgulanan seslerin gerçeklik etkisine olan katkısı görülmektedir. Oyuncuların sesleri yaka mikrofonu ile alınmıştır ve sesin seyirciye olan uzaklığ1 ve derinliği 360 derece olarak alınan ses kaydı ile eşlenmesi ile oluşturulmuştur. Sanal gerçeklik filmlerinde gerçeklik etkisinin yaratılmasında görüntü ile birlikte başta gelen ses kurgusunun bu yapımda başarılı bir şekilde yapıldığını söylemek mümkündür.

\section{Orada Olma Hissi (telepresence)}

İçerisinde herhangi bir oyun motoru veya 3D yazılımı bulunmadan doğrudan 360 derece olarak gerçekleştirilmiş olan içeriklerde "orada olma hissi" için ses kurgusu ve mizansen içerisindeki aksiyonlar önem kazanmaktadır. Anlatı doğal ortam sesleri ve ses efektleri ile desteklenerek 360 derece olarak gerçekten o ormanda olma ve hikâyeyi deneyimleme üzerine kurulmuştur. Selyatağı VR, 360 derece bir video olarak "orada olma hissi" ni oyuncunun kameraya doğru yaptığı hareketler, mekân ve diyalog seslerinin 360 derece olarak nitelikli bir şekilde kullanılması ile başarmış görünmektedir. Selyatağı'nda kullanıcının ormanla etkileşim kurabilmesi, ormandaki ağaçların bakış açısından ortamın içinde olabilmesi ve ses kurgusu ile de sarmalayan yapısı ile 'orada olma hissini' özel bir deneyime dönüştürebilmektedir.

Yapımların çözümlemeleri, yönetmen ile yapımcıların görüşleri ve literatürde daha önce yapılmış çalışma ve yaklaşımlardan yola çıkarak, sinema biçemi ile sanal gerçeklik biçemi arasındaki temel farklara Tablo 2' de yer verilmiştir.

\section{SANAL GERÇEKLIKK DENEYIMI}

\section{Yönetmenin belirlediği pencere ve çerçeve}

Açı, karşı açı, çekim ölçeği, plan vb. öğeler
Kullanıcı tarafından karar verilen 360 derece küresel özgür bir bakış

Çoğunlukla yok / mizansen ve senaryo içerisi düzenleme ile içeriğe 


\begin{tabular}{|c|c|}
\hline & göre değişken \\
\hline Kurgu & $\begin{array}{l}\text { Plan sekansa uygun senaryo ile minimum kurgu veya tamamen CGI } \\
\text { ortamında hazırlanan içeriğe uygun senaryoya dayalı etkileşimli hikaye } \\
\text { kurgusu }\end{array}$ \\
\hline Aygit teorisi & $\begin{array}{l}\text { Kameranın yerine geçerek kenardan olaya tanık olan / olaya } \\
\text { müdahil olan kullanıcı (POV) ve değişen aygıt teorisi ve Platon'un } \\
\text { mağara alegorisi }\end{array}$ \\
\hline $\begin{array}{l}2 \text { boyutlu perdeden } \\
\text { yansiyan } 3 \text { boyutlu } \\
\text { uzam yaratma }\end{array}$ & $\begin{array}{l}\text { Tam } 360 \text { derece ve stereoskopik olarak tasarlanmış mekan ve } \\
\text { derinlik hissi ile mekanı ve hikayeyi doğrudan deneyimleme }\end{array}$ \\
\hline $\begin{array}{l}\text { Hikâyeye güvenli } \\
\text { mesafeden } \\
\text { skopofilik bakış }\end{array}$ & $\begin{array}{l}3 \text { boyutlu uzamın direk içerisinde bulunma ve etkileşime geçerek } \\
\text { sonuca ve anlamlandırmaya etki ederek kullanıcıya dönüşen seyirci }\end{array}$ \\
\hline $\begin{array}{l}\text { Dramatik aydınlatma } \\
\text { / Işık kullanımı }\end{array}$ & $\begin{array}{l}\text { Gerçek mekânda ham ve parçalı kayıt ile post prodüksiyonda veya } \\
\text { mizansen içerisinde doğal aydınlatma ile / hacimsel kayıt ve post } \\
\text { prodüksiyon ile oyun motoru üzerinden limitsiz alternatifli } \\
\text { aydınlatma }\end{array}$ \\
\hline Kesme ve geçişler & $\begin{array}{l}\text { Senaryoya entegre görsel efektler veya planlar ile geçiş / } \\
\text { sinematik veya senaryoya özgü özel geçişler }\end{array}$ \\
\hline Senaryo & $\begin{array}{l}\text { Mümkün olan en uzun ve aralıksız çekime, plan sekansa uygun } \\
\text { tasarlanmış olan, sahne ve mizansen içerisindeki yönlendirme } \\
\text { araçları ve etkileşimli öğeleri detaylı olarak tasarlanmış senaryo }\end{array}$ \\
\hline Mizansen ve oyunculuk & $\begin{array}{l}360 \text { derece olarak olası senaryolara göre hesaplanmış mizansen ve } \\
\text { kesintisiz oyunculuk ile tek seferde yapılan çekim / post prodüksiyon } \\
\text { ile parçalı çekimlerin birleştirilmesi ile }\end{array}$ \\
\hline $\begin{array}{l}\text { Zaman ve mekân kurgusu } \\
\text { / alg1sı }\end{array}$ & $\begin{array}{l}\text { Sinemasal zaman ve mekân ile eş değer olarak zamansal ve } \\
\text { mekânsal olarak hikâyeyi / olayı doğrudan tanık olarak yaşama, } \\
\text { deneyimleme. }\end{array}$ \\
\hline $\begin{array}{l}\text { Kurucu çekim, } \\
\text { açılış sekansı vb. }\end{array}$ & $\begin{array}{l}\text { Tutorial (oyunlarda), sinemadaki örnekleri ikame edebilecek olan } \\
\text { intro metni (örn. Star Wars), dış ses, anlatıcı video veya yazı }\end{array}$ \\
\hline $\begin{array}{l}\text { Diyalog ve ortam } \\
\text { sesleri, foley ve ses } \\
\text { kurgusu }\end{array}$ & $\begin{array}{l}360 \text { derece ambisonic olarak tasarlanmış yönel ses ve foley sesler ile } \\
\text { özel uzmanlık gerektiren ses kurgusu ve mizansen içinde ses ile } \\
\text { yönlendirme }\end{array}$ \\
\hline CGI ve görsel efektler & $\begin{array}{l}\text { Dijital sinemada kullanılan tüm CGI ve görsel efektler ile } \\
\text { etkileşimi sağlayan oyun motorları ile üretilen içeriklerin } \\
\text { entegrasyonu }\end{array}$ \\
\hline $\begin{array}{l}\text { Sahne ve plan içi } \\
\text { hareket ve ses ile } \\
\text { izleyiciyi yönlendirme }\end{array}$ & $\begin{array}{l}\text { Sinemadaki gibi sahne, perspektif ve plan içi hareket ve ses } \\
\text { ile kullanıcıyı yönlendirme, bağlam ve beklenti yaratma }\end{array}$ \\
\hline $\begin{array}{l}\text { Özdeşleşmeyi } \\
\text { sağlayan unsurlar } \\
\text { (ayna, öznel bakış vb.) }\end{array}$ & $\begin{array}{l}\text { Ayna, öznel bakış, ortamla etkileşime geçme, haptik geri bildirim alma } \\
\text { yolu ile ortamı deneyimleme }\end{array}$ \\
\hline $\begin{array}{l}\text { Doğrusal olarak } \\
\text { ilerleyen hikâye akışı ve } \\
\text { son }\end{array}$ & $\begin{array}{l}\text { Kullanıcıların tercihleri doğrultusunda farklı yollardan ilerleyebilen } \\
\text { ve farklı sonuçlanabilen dinamik akış ve anlatı }\end{array}$ \\
\hline
\end{tabular}


Yukarıdaki tabloda yapılan karşılaştırma ve çıkarımlar zamanla örnekler artmaya ve gelişmeye devam ettikçe değişebilecek olmakla birlikte mevcut örnekler ve literatür izleğinde oluşturulmuştur.

\section{Sonuç}

Gerek sanal gerçeklik teknolojisine ait literatüre gerekse de var olan üretilmiş içeriklere bakıldığında bu yeni anlatı aracının kendine has özellikleri olan ancak kendisinden önceki diğer tüm anlatı araçlarının da var olan kodlarından da faydalanan ve geliştiren yeni bir dili olduğu açıktır. Henüz teknolojik olarak son formunu almamış olan hatta hızla ilerleyen teknolojik gelişmeler ışığında gelişmeye devam eden bir teknolojinin, anlatı kodlarına ilişkin kesin ve net kurallar koymak mümkün olmadığı kadar yanlış bir yaklaşımdır. Fakat var olan verilerden hareketle çıkarımlar yapmak ve öngörülerde bulunmak, bu teknolojinin biçemini kavramak ve gelecekteki çalışmalara veri yaratmak açısından önemlidir.

Sanal gerçeklik anlatısının kodlarının izi sürerken örneklem olarak seçilen içeriklerin CVR (Cinematic Virtual Reality) veya TVR (True Virtual Reality) olarak ayırdını yapmak ve içeriğin üretim biçimi ve türü üzerinden çıkarımlarda bulunmak bu aracının dilinin gelişimi bağlaminda en önemli noktalardan birisidir. Ancak her bir içerik kendi bünyesinde farklı kollardan bu dilin gelişimine katkısını sunmaya devam etmektedir. Trinity VR, tam olarak bir TVR içeriği olmamakla birlikte bu teknolojinin yaratım limitlerinin yaratıcıların zihinleri ile sınırlı olduğunun bir göstergesi olması bakımından önemli bir örnektir. İlerleyen dönemlerde sinematik bir görsel kalitede tamamen oyun motoru ile tam etkileşimli bir şekilde tasarlanmış sanal gerçeklik deneyimlerinin üretileceğinin bir göstergesi olan Trinity $V R$, bu konuda öncül bir örnek olarak ayna, sudaki yansımalar vb. öğelerin kullanımı, mekânsal farkındalık için kullanılan yağmur damlaları ile ışık ve gölge kullanımı, hacimsel veriler ile oyun motorunun birlikte kullanılması gibi bazı kodların ve kuralların nasıl kullanılabileceği noktasında da yönlendirici bir çalışmadır. Sanal gerçeklik teknolojisinin verdiği imkanları sonuna kadar zorlamak ve bu yeni aracın dilinin oluşturulmasında öncü çalışmalardan biri olmak üzere önemlidir. Daha fazla oyunsallaştırma daha fazla kullanıcı etkileşimi ile hikâyenin sonucuna doğrudan etki edebilen kullanıcının yaratılabileceğini ve bunun sinemanın kodları ile bir arada kullanılarak bir dil oluşturulabileceğine ilişkin önemli örnekler barındırmaktadır.

Selyatağı VR filmi ise sinemanın kodlarını sanal gerçeklik anlatısına entegre etmeye veya ona uygun bir şekilde dönüştürmeye çalışarak üzerinde detaylı olarak düşünülmüş ve tasarlanmış yerli ve bağımsız bir yapım örneği olarak önemli bir yere sahiptir. Türkiye şartlarında sanal gerçeklik filmlerinin ana akım medyada veya festivallerde henüz yer bulamadığı düşünüldüğ̈ünde yerli üretim bir içeriğin 75. Uluslararası Venedik Film Festivali ile birlikte toplamda 10 farklı festivalde gösterilmiş olması (Tortum, 2019) filmin ne kadar başarılı olduğunun bir göstergesidir. Cannes, Sundance ve Venedik gibi (Bradley, 2017) birçok önemli film festivalinin sanal gerçeklik içeriklerine özel bir bölüm açtı̆̆ göz önünde bulundurulduğunda sanal gerçeklik içeriklerinin yalnızca ana akım ve büyük bütçeli olanlar değil daha bağımsız ve sanatsal olan içeriklerinin de dünya çapında ne kadar önemli olarak görüldüğünün bir göstergesidir. Yuva filmini izleyenlerin hikayesini daha iyi anlayabileceği ama hiç izlemeyenlerin de kendi başına bir hikayesi olduğunu rahatlıkla anlayabildikleri bir ekolojik yıkım karşıtı bir yapım olan Selyatağı VR, görsel kalitesi, mizansen içerisindeki düzenlemeleri ve mizansen içi aksiyon ve ses ile seyircinin yönlendirilmesi bakımından sanal gerçeklik anlatısının dili bağlamında büyük bütçeli yapımlara ihtiyaç olmadan da sinemanın bazı kodlarının sanal gerçeklik diline entegre edilerek dönüştürülmesi ile mümkün olabildiğini göstermesi anlamında iyi bir örnektir. Her ne kadar hem Deniz Tortum'un ifadesinde belirttiği hem de mevcut literatürden de anlaşılabildiği üzere gerçek 
bir sanal gerçeklik deneyimi olmayan, sadece bir 360 derece video formatı da olsa Selyatağı $V R$ gibi daha bağımsız ve görece düşük bütçeli yapımlar da tıpkı büyük bütçeli ve daha etkileşimli yapımlar gibi sanal gerçeklik anlatısının dilinin geliştirilmesi sürecinde önemli bir yere sahiptir. Trinity $V R$ gibi büyük bütçeli yapımların bu yeni teknolojinin anlatısına ilişkin temel kodların belirlenmesinde önemli bir itki güç olduğunu da unutmamak gerekmektedir. Sınırları ve olanakları henüz net bir şekilde belirlenmemiş bir teknolojinin keşfedilebilmesi adına gerekli yatırımları yapmak doğal olarak bütçe gerektiren bir iştir. Dolayısı ile Trinity $V R$ içeriği Selyată̆ı VR filmine nazaran sanal gerçeklik teknolojisinin geleceğine dair daha fazla veri barındırmaktadır. Bu iki farklı içerik te kendi kulvarlarında bu anlatı dilinin kodlarını oluşturmada birbirlerinden faydalanmaya devam edecek gibi görünmektedir.

Genel olarak bakıldığında geleneksel sinemanın anlatısında kullandığı bazı tekniklerin sanal gerçeklik içinde kullanılabilir olduğunu, bazılarının ise dönüşüme uğradığını görmekteyiz. Yönetmenin belirlediği çerçevenin ve kadrajın sanal gerçeklikte kullanıcıya özgür bir bakış açısı olarak dönüşmektedir. Geleneksel anlatıdaki açı-karşı açı, plan ölçek vb. anlatı araçlarının sanal gerçeklikte çoğunlukla yer almadığını ya da mizansen veya senaryo içi düzenlemelerle uygulandığını görmekteyiz. Klasik kurgu plan sekansa uygun bir şekilde dönüşmekte ve senaryoya entegre kesme ve geçiş efektleri ile bir araya gelerek anlatının önemli bir aracı haline gelmektedir. Oyunculuğun ve mizansen kurgusunun senaryo ile birlikte daha fazla birbirine bağlı bir hale geldiğini söylemek yanlış olmayacaktır. Görsel efektler ve ses kurgusu "orada olma" hissiyatını derinleştirmede önemli bir etken olarak daha da fazla önem arz etmektedir. Seyirciyi oyuncu hareketleri ve mizansen içerisindeki ses ve aksiyonlar ile yönlendirme ise tıpkı geleneksel sinemada olduğu gibi sanal gerçeklik anlatısında da önemli bir yere sahiptir ve son derece etkili bir biçimde işlemektedir.

VR yeni anlatım tekniklerini gerekli kilıyor ancak ilk üretimler tıpkı sinemanın yaramaz çocukları gibi gelişen televizyon ve videoda olduğu gibi sinema biçemini taklit etmektedir. Tıpkı sinemasal öyküler içeren video oyunları gibi. Nasıl zamanla televizyon ve video kendi etik ve estetik kodlarını oluşturduysa VR da kendi etik ve estetik kodlarını oluşturacaktır. Ancak, ilk örnekler ağırlıklı olarak sinemasal VR uygulamaları, sinema anlatımı üzerinden ilerlemektedir. VR yapımlarında senaryo ve mizansenin farklı bir önem kazandığını görmekteyiz. Geleneksel sinemada kimi zaman hikâyenin akışına ve senaryonun gereğine göre kullanılan plan sekansların VR yapımlarında daha fazla tercih edildiğini söyleyebiliriz. VR içeriklerinin en temel gücü olan mekân içerisindeki var oluş hissinin daha etkili olarak kullanılması için sürekli değişen plan ve sahneler ters etki oluşturmaktadır. Geleneksel sinemanın da kullandığı mizansen içerisinde ses ve hareket ile seyirciyi yönlendirme VR içeriklerinde de etkin bir şekilde kullanılmaktadır. Sinemasal zaman ve mekânın, kesme ve geçişlerin, dramatik aydınlatma gibi kodların VR içeriklerinde de kullanıldığını söylemek mümkündür. Bununla birlikte sanal gerçeklik deneyimlerinin sinema anlatısından ayrılan en temel noktaları ise, 3 boyutlu bir şekilde derinlik hissiyatını vererek mekânı doğrudan deneyimleme, ambisonic (küre biçiminde tasarlanmış ses dağılım alanı) ses ve diyalog kurgusu sıralanabilir. Tüm bu özelliklere bir de etkileşim ve akışa müdahale eklendiğinde içeriğin formunun ve anlatının daha da farklılaşacağını söylemek mümkündür. CVR ile TVR arasındaki ayrımın gelişen teknoloji ile daha da bulanıklaşacağı düşünüldüğünde temel hareket noktasını oyun motorlarından alan VR deneyimleri dijital oyun ile sinema filmi arasında farklı bir araç olarak kendi biricik formunu ve anlatısını oluşturacaktır. 


\section{Kaynakça}

Ağaoğlu Ercan, E. (2019). Sanal Gerçeklik, Hakikat Kavramının Dönüşümü ve Popüler Kültürdeki Yansımaları. Türkiye İletişim Araştırmaları Dergisi, 34, 115-143

Andrew, J. D. (2010). Büyük Sinema Kuramları. İstanbul: Doruk Yayıncılık.

Aylet, R., Louchart, S. (2003). Towards a Narrative Theory f Virtual Reality, Virtual Reality, Virtual Reality, 7: 2-9.

Bang, E., Yildırım, Ç. (2018). Virtually Empathetic?: Examining the Effects of Virtual Reality Storytelling on Empathy. In: Chen J., Fragomeni G. (eds) Virtual, Augmented and Mixed Reality: Interaction, Navigation, Visualization, Embodiment, and Simulation. VAMR. Lecture Notes in Computer Science, vol 10909. Springer, Cham.

Barthes, R. (1993). Göstergebilimsel Serüven Çev. Mehmet Rifat ve Sema Rifat. İstanbul: Yapı Kredi Yayınları

Basu, A. (2019). A brief chronology of Virtual Reality. New York: Cornell University, arXiv:1911.09605

Baudry, J. L. (1986). Ideological Effects of the Basic Cinematografic Apparatus. In: Philip Rosen (eds.) Narrative, Apparatus, Ideology: A Film Theory Reader. New York: Columbia University Press. 286-298.

Bazin, A. (1966). Çă̆daş Sinemanın Sorunları. Ankara: Bilgi Yayınevi.

Bazin, A. (2011). Sinema Nedir? İstanbul: Doruk Yayıncllık. Publications.

Berger, A.A. (1996). Narratives in popular culture, media and everyday life. London: Sage

Bordwell, D., Thompson, K. (2008). Film Sanatı. Çev. Ertan Yılmaz, Emrah Suat Onay. Ankara: De Ki

Bradley, M. (2017). Top 38 VR Film Festivals to Attend in 2018. https://veer.tv/blog/top-vr-film-festivals-to-attend/, Erişim Tarihi: 06 Nisan 2020.

Brey, P. (2014). The Physical and Social Reality of Virtual Worlds. In: M. Grimshaw (eds.) The Oxford Handbook of Virtuality. 42-54. Oxford: Oxford University Press.

Brown, W. (2013). Supercinema: Film-Philosophy for the Digital Age. New York: Berghahn Books.

Caillois, R. (2006). The Definiton of Play and The Classification of Games. In: Katie Salen ve Eric Zimmerman (eds.) The Game Design Reader A Rules of Play Anthology. 122-155. England: MIT Press.

Crawford, C. (2003). Chris Crawford on Game Design On Game Design. USA: New Riders.

Deterding, S., Khaled, R., Nacke, L. E., Dixon, D. (2011). Gamification: Toward A Definition. http://gamification-research.org/wp-content/uploads/2011/04/02-DeterdingKhaled-Nacke-Dixon.pdf, Erişim Tarihi: 06 Nisan 2020.

Dönmez, S., Erkılıç, H. (2018). 360 Derece Sanal Gerçeklik Uygulamalarını Sinema Kuramı Üzerinden Okumak Mümkün Mü?. Mersin Üniversitesi Sosyal Bilimler Enstitüsü Dergisi, 2 (1), 40-56. 
Elsaesser, T., Hagener, M. (2014). Film Kuramı Duyular Yoluyla Bir Giriş. Çev. Barış Yıldırım, Berhan Soner. Ankara: Dipnot Yayınları.

Fonseca D. (2016). Effect of Immersive (360。) Video on Attitude and Behavior Change, Master Thesis, Aalborg University, Denmark.

Foss, B. (2012). Sinemada ve Televizyonda Anlatım Teknikleri ve Dramaturji. Çev. Mustafa Gerçekler. İstanbul: Hayalperest Yayınevi.

Framingham, M. (2018). Worldwide Spending on Augmented and Virtual Reality Expected to Surpass $\$ 20$ Billion in 2019, According to IDC. https://www.idc.com/getdoc.jsp?containerId=prUS44511118, Erişim Tarihi: 06 Nisan 2020.

Frasca, G. (2001). Rethinking Agency and Immersion: Video Games As A Means Of Consciousness-Raising, Digital Creativity, 12(3), 167-174.

Giannetti, L. (2002). Understanding Movies. New Jersey: Prentice-Hall Inc.

Gödde M., Gabler F., Siegmund D., Braun A. (2018) Cinematic Narration in VR Rethinking Film Conventions for 360 Degrees. In: Chen J., Fragomeni G. (eds) Virtual, Augmented and Mixed Reality: Applications in Health, Cultural Heritage, and Industry. VAMR. Lecture Notes in Computer Science, vol 10910. Springer, Cham.

Gürkan, H, Rengin Ozan. (2014). Butterfly Effect Filmi Örneğinde Karşı Sinemanın Hollywood'da Dönüşümü. Global Media Journal: Tr Edition 4, Bahar (8).

Hamilton, J. (2018). Trinity: Next Level Graphics for Cinematic VR. Unite Berlin 2018. https://www.youtube.com/watch?v=cTqHuIZd-h4, Erişim Tarihi: 06 Nisan 2020.

Harari, Y. N. (2015). Sapiens, Hayvanlardan Tanrılara İnsan Türünün Kısa Bir Tarihi. Çev. Ertuğrul Genç. İstanbul: Kolektif Kitap.

Huizinga, J. (2018). Homo Ludens. Çev. Orhan Düz. İstanbul. Alfa Yayınları.

Isherwood, C. (2016). Prater'in Menekşesi, Çev: Betül Kadığlu. İstanbul:YKY

Jerald, J. (2016). The VR Book Human-Centered Design for Virtual Reality, ACM Books.

Jull, J. (2011). Half-Real: Video Games Between Real Rules and Fictional Worlds, London: The MIT Press Cambridge.

Krucauer, S. (2015). Film Teorisi. Çev: Özge Çelik. İstanbul: Metis

Leotta, A., Ross, M. (2018). Touring the "World Picture": Virtual Reality And The Tourist Gaze, Studies in Documentary Film, 12:2, 150-162. Wadsworth.

Lewis, J. (2014). Essential Cinema: An Introduction to Film Analysis. Boston:

Lombard, M., Ditton, T. (1997). At The Heart Of It All: The Concept of Presence. Journal of Computer-Mediated Communication, Volume 3, Issue 2, 1

Manovich, L. (2001). The Language of New Media. England: The MIT Press Cambridge

Marconi, F., Nakagawa, T. (2017). The Age of Dynamic Storytelling A guide for journalists in a world of immersive 3-D content. AP Insights.

Murray, J. H. (2012). Inventing The Medium. England: The MIT Press Cambridge 
Nash, K. (2018a). Virtually Real: Exploring VR Documentary. Studies in Documentary Film, 12:2, 97-100.

Nash, K. (2018b). Virtual reality witness: exploring the ethics of mediated presence, Studies in Documentary Film. 12:2, 119-131.

Odabaş, B. (2015). Andre Bazin. (eds.) Zeynep Özarslan Sinema Kuramları 1 içinde, 155-180. İstanbul: Su Yayınevi.

Perez, J. M. (2016). Cinematic Virtual Reality: A Definition and Classification Proposal. Treball de fi de grau, Facultat de Ciències de la Comunicació, Departament de Publicitat, Relacions Públiques i Comunicació Audiovisual. Barcelona: Autonomous University. https://www.semanticscholar.org/paper/Cinematic-Virtual-Reality\%3A-A-Definition-andP\%C3\%A9rez-Fossas/ea2e8900e1b9bffe88acb7043d6e1a53bdb07001 Erişim Tarihi: 06 Nisan 2020.

Probst, L., Pedersen, B., Dakkak, L. (2017). Digital Transformation Monitor Augmented and Virtual Reality. Internal Market, Industry, Entrepreneurship and SMEs. $19,116-135$.

Richardson, L. (1990). Narrative and sociology. Journal of Contemporary Ethnography,

Roberts, J. M., Arth, M. J., Bush, R.R. (1959). Games In Culture. American Anthropologist, New Series, Vol. 61, No. 4, 597-605

Sayılgan, Y. (2015). Sinemasal Bir Yaratı Biçimi Olarak Dijital Oyunlar. Marmara Üniversitesi, Güzel Sanatlar Enstitüsü, Sinema ve Televizyon Ana Sanat Dalı, yayımlanmamış yüksek lisans tezi. İstanbul: Marmara Üniversitesi.

Serter, S. S. (2005). Sinemada Biçem: Lütfi Ömer Akad Sineması. Anadolu Üniversitesi, Sosyal Bilimler Enstitüsü, Sinema Televizyon Anabilim Dalı, yayımlanmamış doktora tezi. Eskişehir: Anadolu Üniversitesi.

Sherman, R. W. \& Craig, A.B. (2019). Understanding virtual reality. Cambridge, USA: Morgan Kaufmann.

Sherman, R. W., Craig, A.B., (2003). Understanding virtual reality, California, USA: Elsevier Science.

Sherman, W.R., Craig A.B., Will, J.D. (2009). Developing Virtual Reality Application, Foundation of Effective Design. China: Morgan Kaufmann Publication.

Slater, M., Wilbur, S. (1997). A framework for immersive virtual environments (FIVE): speculations on the ole of presence in virtual environments. Presence Teleoperators Virtual. 6. 603616

Stam, R. (2014). Sinema Teorisine Giriş. Çev. Çiğdem Asatekin, Selda Salman. İstanbul: Ayrintı Yayınları.

Steuer, J. (1992). Defining Virtual Reality: Dimensions Determining Telepresence. Journal of Communication, 42: 73-93.

Sutton-Smith, B. (1999). Overview: Methods In Children's Folklore. In: (eds.) Brain Sutton-Smith, Jay Mechling, Thomas W. Johnson, Felicia R. McMahon. Children's Folklore A Source Book 63-75. Utah: Utah State University Press.

Thomas, S. (2019). The Star in VR. Celebrity Studies, 10:6, 453-468. 
Tortum, D. (2019). Floodplain. https://deniztortum.com/floodplain, Erişim Tarihi: 06 Nisan 2020.

Tortum, D. (2019). Sanal Gerçeklik Atölyesi. 8. Atıf Yılmaz Kısa Film Festivali. Atölye ve Söyleşiler. Mersin. http:/ / atifyilmazkisafilm.com/program/, Erişim Tarihi: 06 Nisan 2020.

Uricchio, W. (2016). Putting VR in Perspective. Keynote: Virtually There: Documentary Meets Virtual Reality. MIT Open Documentary Lab. https:// www.youtube.com/watch?v=SR5xRESAt98, Erişim Tarihi: 06 Nisan 2010

Ünal, R., Dönmez, S. (2018). 360-Degree Video News Reporting. In: (eds.) Nurettin Güz, Ceren Yegen, Media With Its News, Approaches And Fractions In The New Media Age Berlin: Peter Lang.

Witmer, B., Singer, M. J. (1998). Measuring Presence in Virtual Environments: A Presence Questionnaire. U.S. Army Research Institute for the Behavioral and Social Sciences.

Yeksan, E. (2019). Sanal Gerçeklik Atölyesi. 8. Atıf Yılmaz Kısa Film Festivali. Atölye ve Söyleşiler. Mersin. http:/ / atifyilmazkisafilm.com/program/, Erişim Tarihi: 06 Nisan 2020.

Yengin, D. (2012). Dijital Oyunlarda Şiddet. İstanbul: Beta. 